\title{
5. SHALLOW-WATER SKELETAL DEBRIS AND LARGER FORAMINIFERS FROM DEEP SEA DRILLING PROJECT SITE 462, NAURU BASIN, WESTERN EQUATORIAL PACIFIC ${ }^{1}$
}

\author{
Isabella Premoli Silva and Chiara Brusa, Istituto di Paleontologia,Università di Milano, \\ Piazzale Gorini 15, Milano, Italy
}

\begin{abstract}
Shallow-water larger foraminifers and associated forms adapted to a reef environment were recovered from Deep Sea Drilling Project Hole 462, drilled in 5181 meters water depth in the Nauru Basin, south of the Marshall Islands. Shallow-water material, mainly reworked, (1) is frequently associated with volcaniclastic breccias to coarse sands, (2) occurs episodically interbedded within a turbiditic sequence whose clasts are pelagic components (planktonic foraminifers, radiolarians, and calcareous nannoplankton). More than 60 species of larger foraminifers were identified, and most of them are age-diagnostic. They range in age from Campanian to late Oligocene; only a few forms are attributable to the mid-Cretaceous.

A comparison was made with similar shallow-water assemblages recovered from deep sites previously drilled in the central western Pacific (Line Islands, Tuamotu Ridge). On the basis of the occurrence of larger foraminifers (1) the existence of volcanic edifices capped by reefs is demonstrated for the mid-Cretaceous; late Campanian through late Maestrichtian; early, middle, and late Eocene; early Oligocene; and late Oligocene; (2) five main discrete erosional events are identified since the late Cretaceous; they are dated at middle(?)-late Maestrichtian, late(?) Eocene, early late Oligocene, and middle Miocene; (3) larger-foraminifer assemblages display great affinities with the Caribbean bioprovince during the Cretaceous, whereas they contain mainly Tethyan and/or Indo-Pacific elements during the Tertiary; and (4) the main direction of faunal migration from westward (Caribbean) during the Late Cretaceous was reversed during the Tertiary.
\end{abstract}

\section{INTRODUCTION}

The present chapter treats larger foraminifers and other shallow-water debris, primarily recovered from DSDP Hole 462, drilled at 5181 meters water depth, in the Nauru Basin, western equatorial Pacific.

Shallow-water faunas and floras with forms adapted to the reef environment, anomalously occurring at such oceanic depth, are frequently associated with volcaniclastic material and are contained in generally graded layers, including volcaniclastic breccias, fine conglomerates, and coarse foraminifer sands. Such coarse layers are episodically interbedded in a turbiditic sequence, where the dominating grain-size ranges from a foraminifer and/or radiolarian sand to a nannofossil silt (see Premoli Silva and Violanti, this volume).

The age of planktonic faunas and floras associated and/or containing the coarse layers ranges from late Campanian through Quaternary. Such layers are unevenly distributed throughout the stratigraphic column: they are more common during intervals of major erosion (late Campanian, middle-late Maestrichtian, late Eocene, early late Oligocene, late Oligocene, and middle Miocene.

Autochthonous sediments are red clay, yielding mainly fish debris and abyssal, non-calcareous, benthic foraminifers, and occasionally possible autochthonous radiolarians (see Premoli Silva and Violanti, and Premoli Silva and Sliter, this volume). The oldest shallow-water fossils are Late Cretaceous (CampanianMaestrichtian); they are partly reworked into the Tertiary. Shallow-water fossils are also diagnostic of early

\footnotetext{
${ }^{1}$ Initial Reports of the Deep Sea Drilling Project, Volume 61.
}

Eocene, middle and late Eocene, early late Oligocene and late Oligocene ages. A few forms, mainly in the upper levels, are probably Neogene or younger.

The most commonly represented taxonomic groups are larger foraminifers, including Discocyclinidae, Miogypsinidae, Nummulitidae, Orbitoididae, Pseudorbitoididae, bryozoans, and more rarely coralline algae. Mollusks, corals, and echinoids are minor components and commonly very fragmented.

\section{COMPOSITION OF THE COARSER LAYERS}

On the basis of their composition, both organogenic and inorganic, the coarser layers can be grouped as follows:

1) Layers from the upper (younger) part of the sequence (mainly from Core 5, Section 7, through Core 6, Section 2), in which shallow-water material is scarce, poorly diversified, never exceeding the 3 to $5 \%$ of the $>63-\mu \mathrm{m}$ fraction. Volcanic material mainly consists of fresh glass and ash, which sometimes cements planktonic foraminifers and radiolarians. Volcanic material may represent $50 \%$ of the $>63-\mu \mathrm{m}$ fraction.

2) Layers corresponding to the typical foraminifer sands, in which shallow-water material is scarce, poorly diversified, never exceeding $15 \%$ of the $>63-\mu \mathrm{m}$ fraction, dominated by planktonic foraminifers. The larger foraminifers cover a long time interval, but are few and mainly reduced to small fragments, often with very chalky, poorly preserved inner parts. Volcanic material is present as a minor component of the $>63-\mu \mathrm{m}$ fraction. Those layers are common in Cores 14, 23, 25, and 27.

3) Layers, recorded from Core 21, Section 1; Core 22, Section 1; Core 32, Sections 1 and 2; and Core 34, Sections 1 and core catcher in which the shallow-water 
material is highly diversified and belongs to moredifferentiated paleo-environments. The identified foraminifer assemblages range from Late Cretaceous to late Oligocene. Volcanic material includes glass in various stages of alteration and a large amount of fragments of volcanic rocks, dominated by basalts. Lithic fragments, both calcitic and cherty, are also present.

4) In the oldest layers, recorded from Core 48 , Sections 1 and 2; Core 51, Section 3; and Core 52, Section 1, (Late Cretaceous), shallow-water material is homogeneous, mainly larger foraminifers of similar age. Other biogenic components are possibly represented by minute calcitic fragments, which are undiagnostic. In Core 48, Sections 1 and 2, inorganic material, mainly consisting of small fragments of volcanic glass and opaline silica, is a minor component. In Core 51, Section 3; and Core 52 , Section 1, shallow-water forms are included in graded layers of coarse to very coarse volcaniclastic breccia, passing upwards into volcaniclastic sandstone. Biogenic components are similar to those described from Core 48, and include larger foraminifers, together with small calcitic biogenic fragments. Inorganic components are abundant and include relatively large blocks of basalts, pyroxenes, and abundant glass. The lowermost breccia, recorded from Core 52, Section 1, $110-150 \mathrm{~cm}$, of late Campanian age, contains only undiagnostic but possibly older biogenic fragments (midCretaceous?).

The distribution of biogenic and inorganic components throughout the sedimentary succession recovered at Hole 462 is shown in Figure 1.

\section{FOSSIL ASSEMBLAGES}

The shallow-water material recovered from Hole 462 represents one of the largest assemblages ever recorded from Pacific drill sites; it is outstanding in diversity, number of species, taxonomic groups, and stratigraphic range. More than 60 species of foraminifers, red algae, corals, hydrozoans, bryozoans, etc. have been identified. Their occurrence and abundance are reported in the range chart in Figure 2.

In some cases, the poor state of preservation prevented full identification of the species; some identifications must be considered only as preliminary. Larger forms ( $>3 / 4 \mathrm{~mm}$ ) were found broken, commonly with eroded edges; relatively smaller forms display different stages of recrystallization even at the same levels: a positive correlation exists between age and state of preservation, the oldest forms being more chalky than the younger ones. Among the nummulitids, the older specimens are chalky and filled with calcite, whereas the younger representatives are empty and relatively well preserved. Some other foraminifers, such as pseudorbitoidids, are externally well preserved, although the inner characters are unrecognizable.

All the examined specimens were first studied under the binocular microscope, then described. Some forms displaying characteristic outer features, such as Asterorbis, Asterocyclina, and Vaughanina, could be identified at the generic level in this first observational stage. Oriented thin sections were prepared from most speci- mens. Additional information was obtained from thin sections made randomly from the coarser fractions of washed residues. In some cases, regular thin sections were prepared, mainly from the indurated samples of Hole 462A. Specimens belonging to the genera Nummulites and Assilina were opened along the periphery (marginal cord) after being strongly heated and then soaked in cold water. Both external and internal characters can be observed in this way. More than 300 isolated specimens were prepared with the methods mentioned above; however, only $50 \%$ of them could be identified at the specific level because of poor preservation.

\section{DISCUSSION ON THE AGE OF SHALLOW-WATER DEBRIS}

Larger foraminifers are by far the most conspicuous components among the reef-derived skeletal debris. Moreover, several identified species are stratigraphically important. Other reef-derived skeletal debris is too fragmentary to be stratigraphically diagnostic. This study therefore concentrates on the larger foraminifers, among which a relatively large number of age-diagnostic assemblages can be recognized. They are as follows (from bottom to top):

\section{Late Cretaceous}

In the late Campanian to middle Maestrichtian, two assemblages are distinguishable: (1) an older one, occurring in Core 5, Section 1; and Core 51, Section 3, is characterized by Pseudorbitoides israelskyi, Sulcoperculina vermunti, and Vaughanina cubensis. They are associated with planktonic-foraminifer faunas of the Globotruncana subspinosa and Globotruncana calcarata Zones (in Cores 52 and 51, respectively), dated as late Campanian; the age suggested by the "guest" planktonic assemblages is consistent with the stratigraphic range known for $P$. israelskyi and $S$. vermunti (Brönimann, 1957); Brönnimann (1957) however claims that true $P$. israelskyi never overlaps the range of $V$. cubensis, a species confined to the Maestrichtian; the material from Hole 462, being displaced, does not help to resolve this problem; (2) the second (younger) assemblage (Core 48, Sections 1 and 2) is characterized by Lepidorbitoides bisambergensis, L. minor, L. socialis, Orbitocyclina minima, Asterorbis havanensis, and $A$. rooki, associated with Sulcoperculina vermunti, $S$. cubensis, and rare representatives of Pseudorbitoides and poorly preserved Vaughanina. The planktonicforaminifer assemblages in Core 48 are characteristic of the Globotruncana gansseri Zone, of middle Maestrichtian age; among the Lepidorbitoides, the identified species $L$. bisambergensis, $L$. minor, and $L$. socialis, according to van Gorsel (1975), represent three evolutionary stages of the same lineage, $L$. socialis being the end member, confined to the uppermost Maestrichtian, thus corresponding to the planktonic-foraminifer zone of Abathomphalus mayaroensis and L. bisamergensis, the oldest species, ranging from the early Maestrichtian Globotruncana tricarinata Zone through the middle part of the Globotruncana gansseri Zone (middle Maestrichtian in this volume), and L. minor between the two 
mentioned species, ranging from the upper part of the $G$. gansseri Zone to the base of the A. mayaroensis Zone ( = late middle Maestrichtian).

This being so, it seems likely that the co-occurrence of the three species in Core 48, Sections 1 and 2 is an artifact, and both $L$. bisambergensis and $L$. minor (the latter with less certainty) must be reworked. Moreover, if the correlation between species ranges within the Lepidorbitoides and planktonic-foraminifer zones is confirmed by further studies, we must assume also that the planktonic-foraminifer faunas co-occurring with $L$. socialis, attributed to the middle Maestrichtian $G$. gansseri Zone, are also reworked into the late Maestrichtian. Planktonic foraminifers indicating the $A b a$ thomphalus mayaroensis Zone, or even the underlying Globotruncana contusa Zone, are lacking in Core 48 (see Premoli Silva and Sliter, this volume), but are found reworked in several Tertiary layers (see Premoli Silva and Violanti, this volume).

Rare Late Cretaceous larger foraminifers and rudistid fragments occur also in Core 21, Section 1, 2-3 $\mathrm{cm}$; and in Core 22, Section 1, 69-71 cm, dated as late Oligocene (Globigerina angulisuturalis Zone $=$ Zone P22).

A single specimen belonging to the Family Orbitolinidae was found in Core 32 , Section $1,5-8 \mathrm{~cm}$, and dated as late early Oligocene. Precise identification was prevented (the specimen was lost in transit), but it possibly belonged to the mid-Cretaceous stock.

\section{Tertiary}

The following assemblages occur mainly mixed together in some samples from Core 34, Sections 1 and CC; Core 32, Section 1; Core 22, Section 1; and Core 21 , Section 1, 2-3 cm (numbering continued from Late Cretaceous section): (3) an older Tertiary assemblage characterized by nummulitids, among which Assilina leymeriei, Nummulites pernotus, $N$. burdigalensis minor, $N$. partschi, and $N$. rotularius have been identified after a comparison with topotype material; all are described from early Eocene strata of the Mediterranean area and have not been reported from the Indo-Pacific; according to Schaub $(1951,1961,1963), A$. leymeriei and $N$. pernotus characterize the lower part of the early Eocene, while the other two species occur primarily in the middle to late early Eocene; at Hole 462, the two first forms occur in Core 34, Section 1 , which contains late Eocene planktonic foraminifers of the Turborotalia cerroazulensis Zone, and in Core 32, Section 1; Core 22, Sections 1 and 21 (early late and late Oligocene), where they are associated with the other three species; (4) other species, still Eocene in age, but younger than assemblage (3), have been identified in Core 32 , Section 1 , and in Core 22, Section 1, 69-71 cm, dated on the basis of the associated planktonic foraminifers as late early Oligocene (P19/P20 zone boundary), and as late Oligocene (P22), respectively; they are Nummulites sp. aff. $N$. variolarius, $N$. problematicus, $N$. sp. cf. $N$. bagelensis, Operculina eniwetokensis, Heterostegina saipanensis, Spiroclypeus sp. cf. $S$. vermicularis, $S$. sp. cf. S. albapustula, Asterocyclina matazensis, A. penuria,
Polylepidina antillea, and P.? sp. aff. P. paucispira; those species have a different range within the middle to late middle Eocene, and moreover are known from different bioprovinces; in particular, Polylepidina antillea characterizes middle to late middle Eocene layers of the Caribbean, whereas Nummulites bagelensis, possibly a junior synonym of $N$. javanus according to Adams (1970), is recorded throughout the middle Eocene of the Indo-Pacific region; Asterocyclina penuria, A. matazensis, Operculina eniwetokensis, Spiroclypeus vermicularis, and S. albapustula are all recorded in the late Eocene portion of the Eniwetok drill hole (Cole, 1957); all the species except Operculina eniwetokensis are characteristic of the late Eocene of the Indo-Pacific region, or have even larger distribution, such as the Spiroclypeus, known also from the Mediterranean area; among the nummulitids, the identified species are Nummulites problematicus and $N$. sp. aff. $N$. variolarius: the former is known from the Mediterranean region, where its range spans the late Eocene and the early Oligocene (Pavlovec, 1966); the latter is the only Nummulites recorded from the central Pacific (see Beckmann, 1976, on DSDP Site 318, Tuamotu), but occurs also in the Indo-Pacific region in layers dated as late Eocene (Doornink, 1932); however, N. variolarius is known from the middle Eocene of the Paris Basin (Blondeau, 1980); many other specimens which could not be identified specifically broadly indicate an Eocene age: most of them belong to the genera Discocyclina, Asterocyclina, Nummulites, and Operculina; they could not be assigned to a specific stratigraphic level; this group also included a single alveolinid, probably attributable to Fasciolites (= Alveolina); the very poor state of preservation prevented better identification; (5) in Core 32, Sections 1 and 2, other species of Nummulites, such as $N$. bouillei and $N$. vascus, also occur; their range is restricted to the early-middle Oligocene (P18 to top P20; see Haak and Postuma, 1975); their presence in Core 32, Sections 1 and 2 (early Oligocene, P19/P20 zone boundary) is in agreement with the age inferred from planktonic foraminifers; Nummulites problematicus, whose range, as mentioned above, straddles the Eocene/Oligocene boundary, could also belong to this assemblage; the species mentioned above occur reworked in Core 22, Section 1, 69-71 cm, and Core 21, Section 1, 1-3 cm, dated as late Oligocene; the Globigerina angulisuturalis Zone (P22) is younger than the extinction level of Nummulites in the Indo-Pacific region, as well as in the Mediterranean; (6) Heterostegina borneensis, Lepidocyclina (Eulepidina) sp. cf. L. ephippioides, and Nephrolepidina sumatrensis occur only in Core 22, Section 1, 69-71 cm, attributed to the late Oligocene Globigerina angulisuturalis Zone (P22); according to Adams (1970), H. borneensis occurs primarily in the late Oligocene (P21/P22); N. sumatrensis appears in the uppermost part of P22, then continues into the Miocene; Eulepidina and possibly Eulepidina ephippioides appear at the base of P19 (early Oligocene) according to Haak and Postuma (1975), and are still recorded from Miocene layers; these species represent a late Oligocene assemblage; other species, such as Het- 


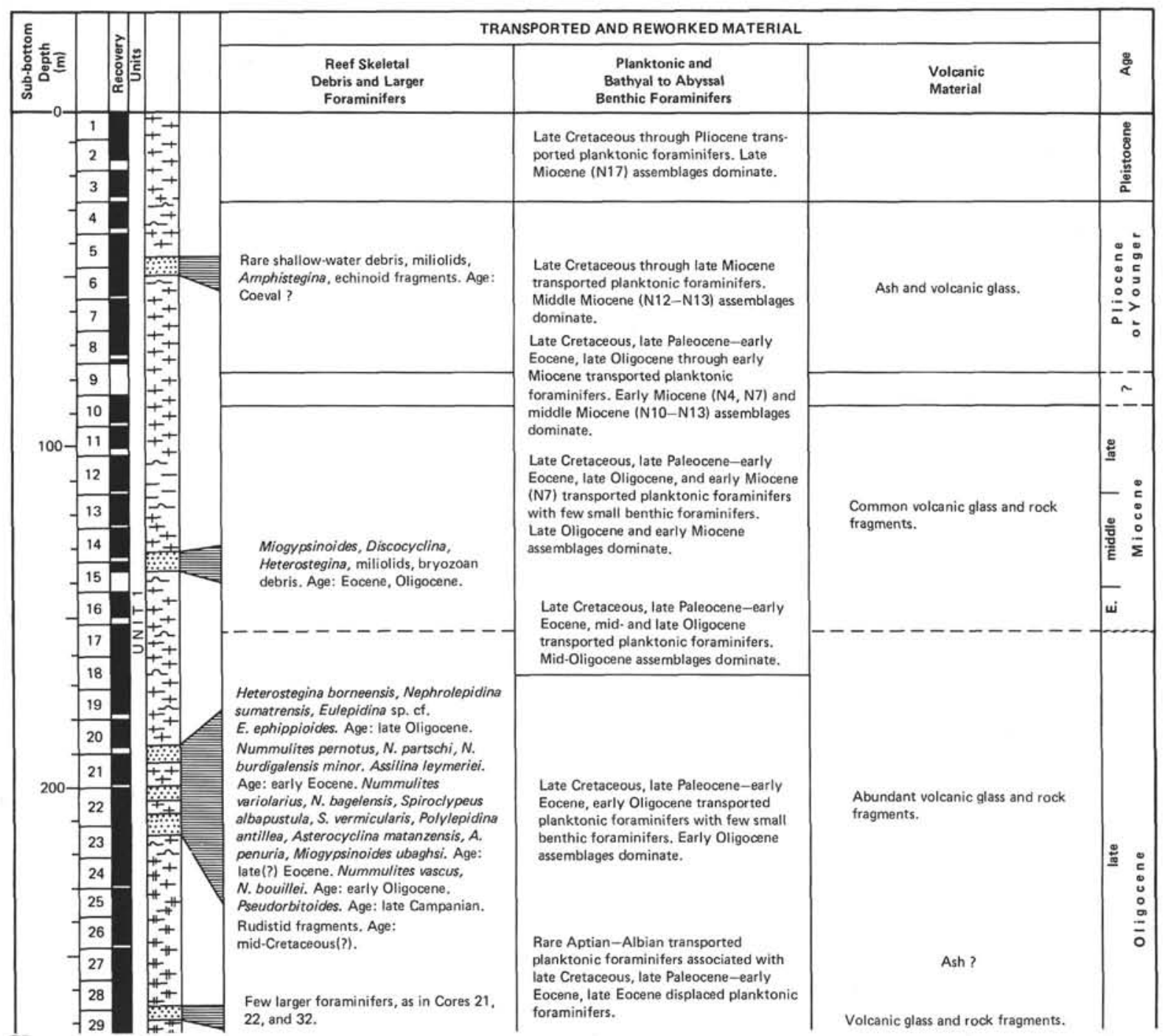




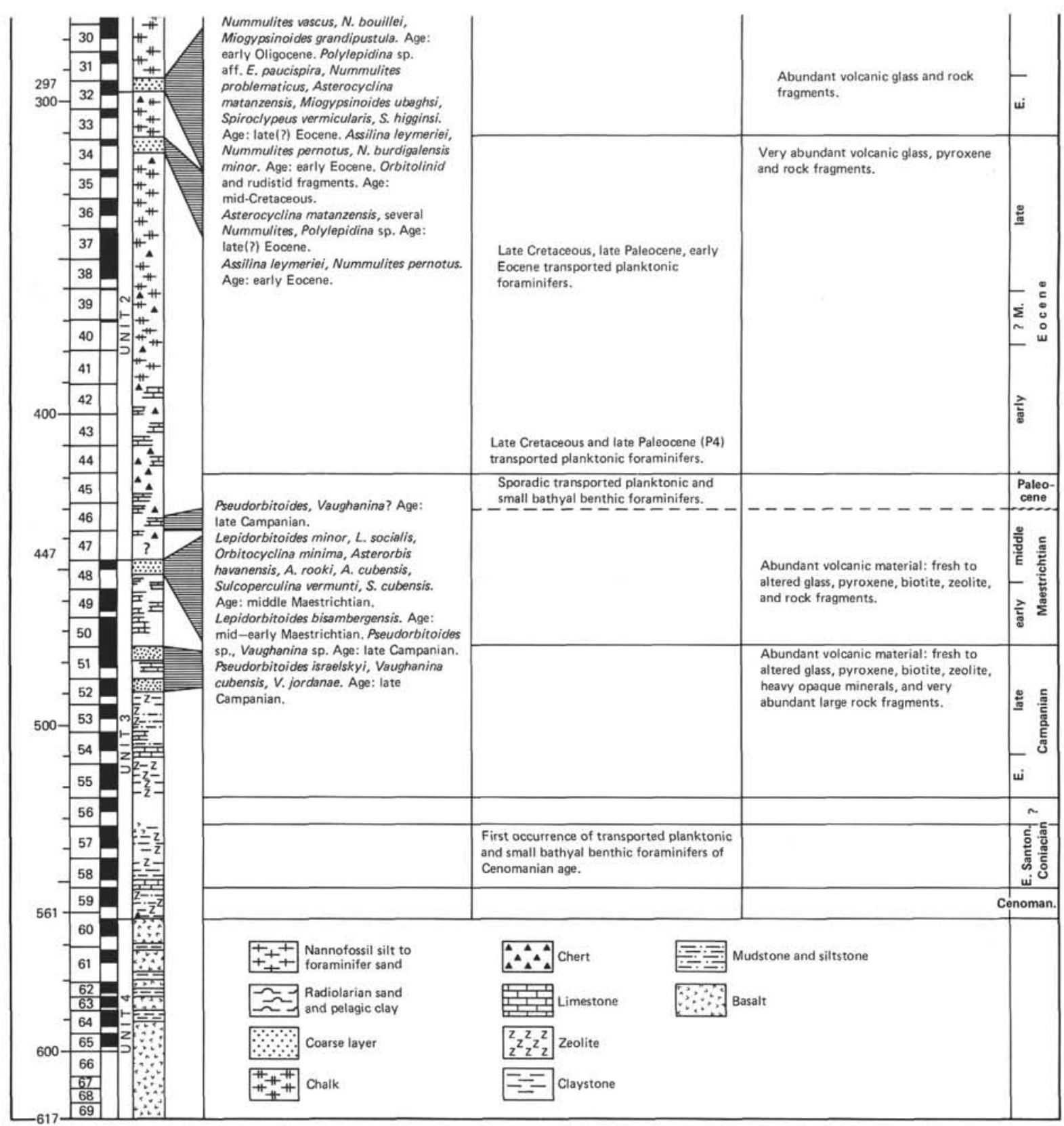

Figure 1. Distribution in DSDP Hole 462 of transported and reworked material, including larger foraminifers and reef skeletal debris, planktonic and bathyal to abyssal benthic foraminifers, and volcanic material, plotted against depth, lithology, and age. 


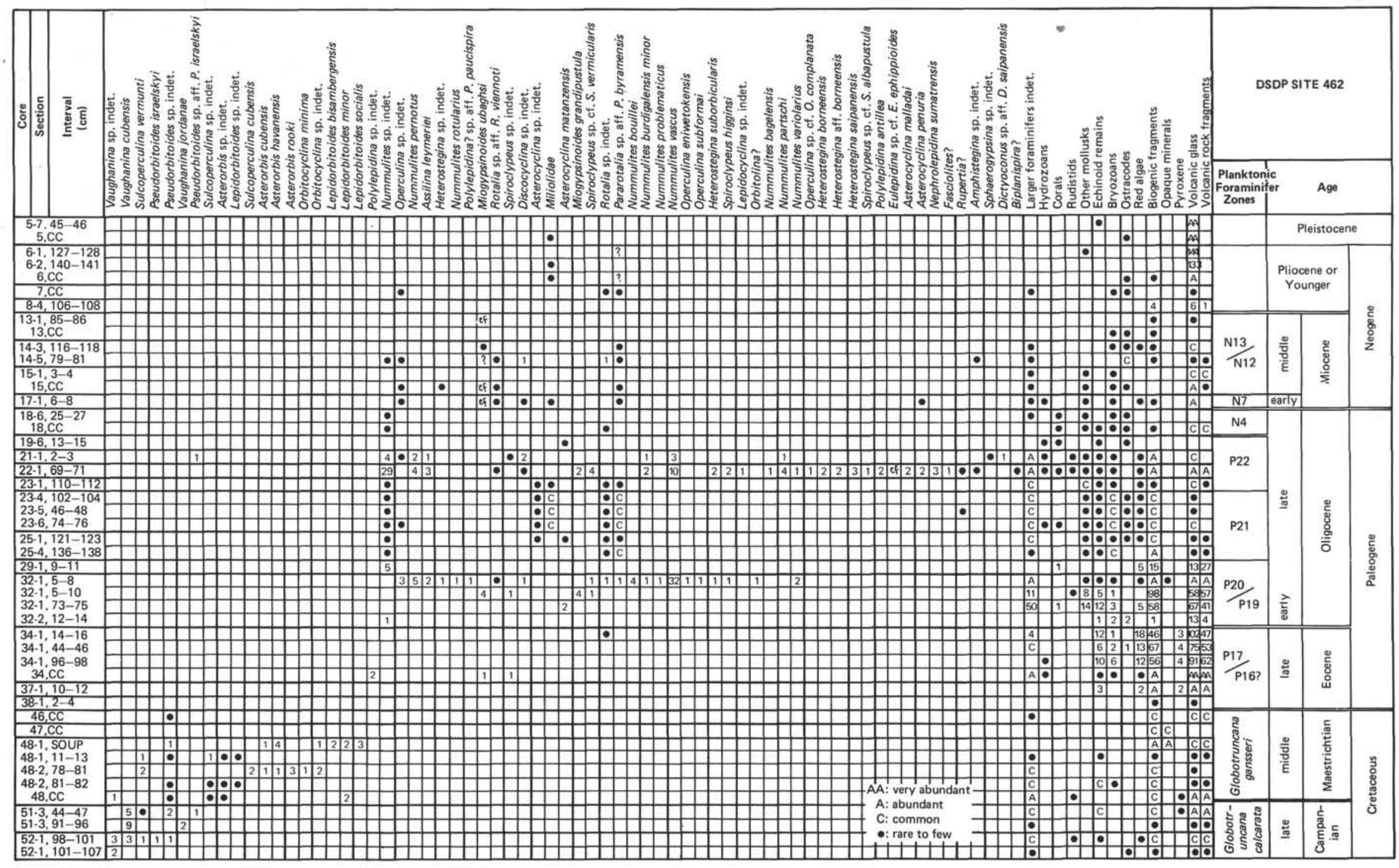

Figure 2. Distribution of larger foraminifers, other shallow-water debris, and volcanic material in Hole 462 . Numbers refer to quantitative analysis done for some samples treated on shore (see Premoli Silva and Violanti, this volume). Sample 46,CC was studied in thin section. 
erostegina suborbicularis, $H$. subformai, and some rotaliids, have such long ranges that they are not indicative of a specific stratigraphic level; (7) some amphisteginids and miliolids occur in Cores 6 and 5, which are attributed to the Pleistocene; they may represent a Plio-Pleistocene assemblage.

\section{The Occurrence of Miogypsinoides}

Two species of Miogypsinoides were identified in Hole 462: Miogypsinoides ubaghsi in Core 34, Sections 1 and CC; Core 32, Section 1; and Core 22, Section 1, 69-71 cm; and $M$. grandipustula in Core 32, Section 1 . A few fragments possibly attributable to $M$. ubaghsi were also recorded from Cores 17, 15, and 14, higher in the sequence (Miocene). As mentioned above (see also Figs. 1 and 2), Cores 34 and 32 are dated on the basis of planktonic faunas (foraminifers and radiolarians) and floras as late Eocene (Turborotalia cerroazulensis Zone) and late early to early late Oligocene (P19/P20), respectively. Core 22 belongs to the late Oligocene Globigerina angulisuturalis Zone (P22).

Drooger (1963) regarded Miogypsinoides ubaghsi as a junior synonym of $M$. complanatus. Direct comparison with the original material from the Eniwetok drill hole allows us to state that our specimens belong to the same species from Eniwetok found in Cole's (1957) collection. Moreover, the spiral length, the very large $A-P$ angle $\left(\sim 400^{\circ}\right)$, and the shape of the equatorial chambers differentiate both ours and Cole's specimens from either $M$. complanatus or $M$. bantamensis (see Hanzawa, 1962). The characters above-mentioned would make instead our specimens closer to $M$. ubaghsi, to which species the specimens from Hole 462 are attributed. According to the literature (Adams, 1970; Haak and Postuma, 1975; etc.), Miogypsinoides ubaghsi is mainly confined to the late Oligocene. Then, its occurrence in Core 22, Section 1, 69-71 cm, is consistent with the age inferred from the host foraminifer faunas, attributed to the late Oligocene Globigerina angulisuturalis Zone ( $\mathrm{P} 22)$.

On the other hand, Miogypsinoides in Core 34, Section 1 (late Eocene) and in the Core 32, Sections 1 and 2 (early/late Oligocene boundary) has important biostratigraphic implications.

The oldest record of Miogypsinoides is from middle Oligocene strata of Java (Tan, 1932). Tan's finding, however, was never confirmed elsewhere. Adams (1970) seriously doubts that Tan's identification of Miogypsinoides could be correct (the specimen was neither figured nor described), and secondly he remarks that the age of the formation in which Miogypsinoides occurs is very questionable. According to Adams (1970), no true Miogypsinoides have been proved to occur earlier than the late Oligocene.

The occurrence of verifiable representatives of Miogypsinoides in Hole $\mathbf{4 6 2}$ within layers dated as late Eocene and early/late Oligocene would make the first appearance of this genus much earlier than was previously believed. However, this reasoning would imply that Miogypsinoides, a genus displaying very rapid evolution throughout the late Oligocene, at the beginning of its range evolved only very slowly. In particular, the species $M$. ubaghsi would maintain the same nepionic acceleration stage for about 10 m.y. (from late Eocene at, $\sim 37$ m.y. ago, to topmost Oligocene, $\sim 23 \mathrm{~m} . \mathrm{y}$. ago): that is to say an unprecedented, totally unexpected behavior among the larger foraminifers. More reasonably, we can think that because of the turbiditic character of the whole sedimentary sequence of Hole 462 , all planktonic components (calcareous nannofossils, planktonic foraminifers, and radiolarians) associated with Miogypsinoides may not only be transported, but might be totally reworked (see Premoli Silva and Violanti, this volume). Therefore, they would lead to a dating of the sediments much older than they in fact are.

In conclusion, at Hole 462 the sediments yielding Miogypsinoides ubaghsi cannot be older than the first appearance of the genus Miogypsinoides, which according to Adams (1970) would occur at the base of the late Oligocene $(=$ lower $\mathrm{Te}=\mathrm{P} 21$; Globorotalia opima opima Zone; Haak and Postuma, 1975) (Fig. 3). Consequently, Core 34 must be dated at least as late Oligocene (P21), and it would be not late Eocene in age, as inferred from the planktonic components; the overlying cores, at least up to Core 27 , have to be rejuvenated as well. The representatives of Miogypsinoides become a conspicuous component of the late Oligocene assemblage (6).

\section{Skeletal Debris}

Few fragments of shallow-water skeletal debris display enough characters to make them identifiable (Plates 19 and 20). They belong to milleporinid hydrozoans (Axopora?), to Scleractinia (Stylophora, Porites, Actinastrea?, Seriatopora), to Octocorallia (Alcyonocean), and to cyclostomate bryozoans (determination by S. Frost). They occur primarily in Core 22, Section 1, 69-71 cm (late Oligocene) except Stylophora from Core 34, CC. Their distribution is mainly from Eocene, or even older levels, to Recent. A more restricted range (Eocene-Oligocene) is known from the genus Axopora. Their range is consistent with those of the associated larger foraminifers, except for Seriatopora, known only from Miocene to Recent in the Indo-Pacific region. As already mentioned, rare rudistid fragments occur in Cores 21 and 22 (Plate 19), reworked along with Late Cretaceous larger foraminifers. In the Late Cretaceous of Cores 48,51 , and 52 , very rare fragments can be only doubtfully referred to the rudistids. Those fragments suggest a Cretaceous age.

\section{OCCURRENCE OF REEF-DERIVED SKELETAL DEBRIS AT OTHER PACIFIC DRILL SITES}

Allochthonous, reef-derived skeletal debris was recorded from several drill sites during previous DSDP legs in the central and western Pacific. Most of those drill sites are close to volcanic island chains, such as Line Island (Sites 165, 315, 316), Tuamotu Ridge (Site 318), Mid-Pacific Mountains (Sites 171, 313), Caroline Ridge (Site 58), and Western Pacific Seamounts (Site 


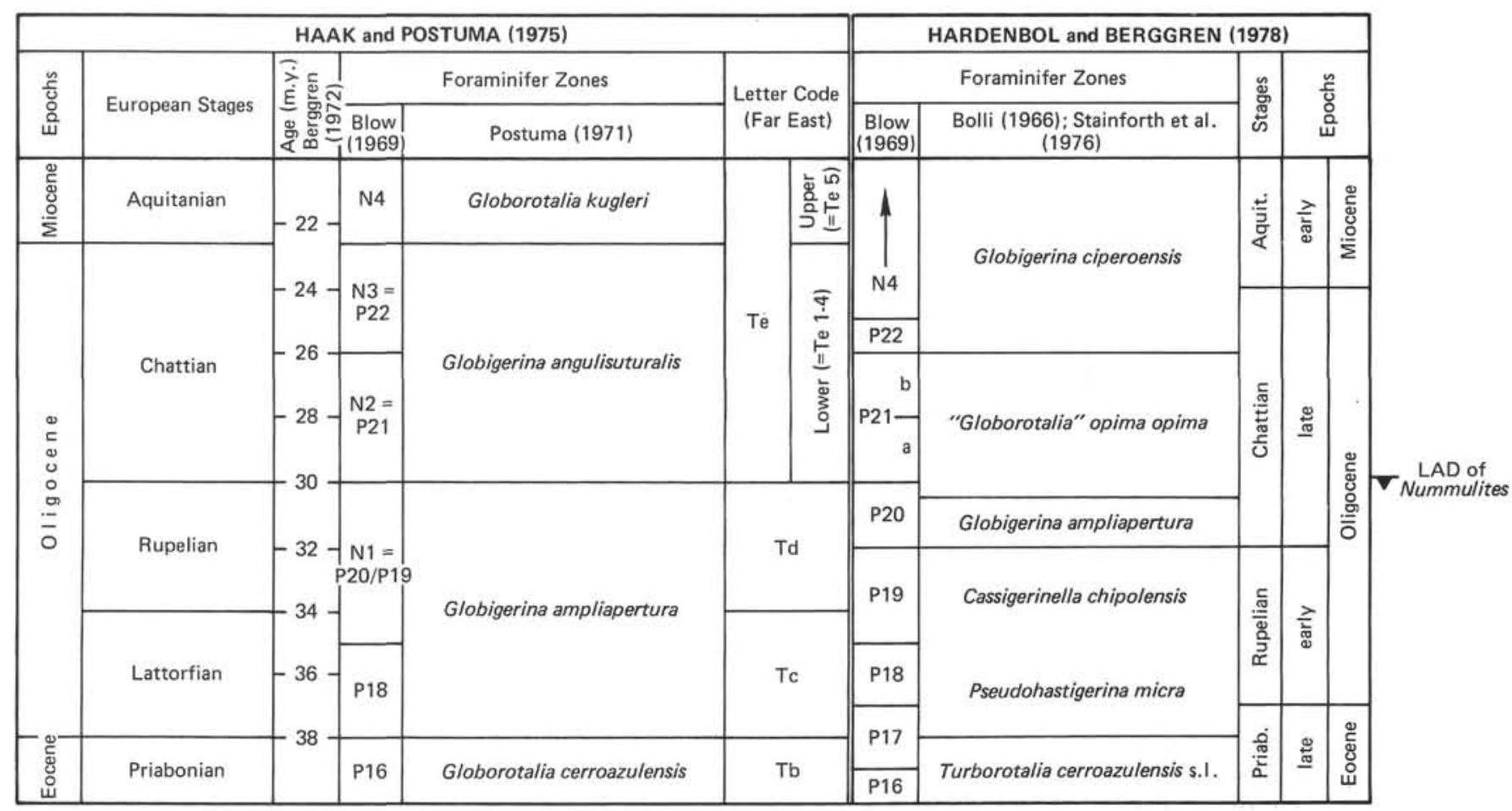

Figure 3. Zone scheme. Note that in Hardenbol and Berggren (1978) the age of the Eocene/Oligocene and Oligocene/Miocene boundaries changed to $37 \mathrm{~m} . \mathrm{y}$. and to $24 \mathrm{~m} . \mathrm{y}$., respectively.

202). At some of these sites, such as Sites 202, 313, 171, and 58 , shallow-water material is poorly age-diagnostic, and correlations with Hole 462 are only tentative.

On the other hand, sites drilled close to the Line Islands, and to a lesser degree those closer to the Tuamotu Ridge, show a striking similarity to Hole 462 insofar as the faunas and age determinations are concerned.

The correlations presented in Figure 4 are based on the original Initial Reports descriptions completed by new observations (1) of the original cores (visual), (2) on direct comparison between Hole 462 material and the original material studied by Beckmann (1976) for his Leg 33 Report, and (3) on a set of thin sections prepared by E. L. Winterer for petrographic purposes, which were kindly made available for the present study.

Starting from the older levels, the first correlation concerns the volcaniclastic sequence, dated as early(?)late Campanian. This sequence is poorly fossiliferous at its base. However, at Site 315, Core 22, Section 4, 145 $150 \mathrm{~cm}$, representing the coarser part of a graded volcaniclastic sandstone, contains little shallow-water debris and other intraclasts of older age, including fragments of mid-Cretaceous Cuneolina and Solenoporacea. The same forms also occur at Site 171, Cores 29 to 31 , dated on the basis of planktonic foraminifers as late Cenomanian. Of comparable age are also some fragments of Orbitolina dredged at Isakov Guyot (Heezen et al., 1973) and the single orbitolinid recorded at Hole 462 , reworked in the early late Oligocene of Core 32.

Assemblage (1), of Hole 462, characterized by Pseudorbitoides, Sulcoperculina, and Vaughanina, also oc- curs at Site 165 (Core 17A), close to the Campanian/ Maestrichtian boundary, and at Site 316 (Cores 27-23) in the late Campanian Globotruncana calcarata Zone. At Site 315 , only pelagic sediments are recorded from this interval.

Assemblage (2), with Lepidorbitoides, Sulcoperculina, and some pseudorbitoidids, is recorded at Site $\mathbf{3 1 5}$ (Cores 17A and 18A) in the middle Maestrichtian Globotruncana gansseri Zone, and at Site 165 (Core $16 \mathrm{~A}, \mathrm{CC})$; the microfacies of the latter sample is identical to that of Core 46, CC at Hole 462. According to Douglas (1973), Core 16A,CC (Site 165) is attributable to the late Maestrichtian Abathomphalus mayaroensis Zone, but this age assignment is weak, because of the poor planktonic fauna.

The same assemblage, as rich in species as in Core 48 (Hole 462), is recorded at Site 315, reworked in Core 10A (early Oligocene) and in Core 9A (late Oligocene), associated with representatives of assemblage (1). A few Late Cretaceous forms are also recorded from Site 462, reworked in the same intervals.

Assemblage (3), dated as early Eocene, and composed mainly of Nummulites, previously has not been recorded from Pacific drill sites. The assemblage which best approximates the faunas of Hole 462 is the Discocyclina-Asterocyclina assemblage recovered at Site 318, Core 32 (Tuamotu Ridge). In this core, the shallowwater fauna and flora are associated with a planktonic fauna attributed to the late early Eocene Acarinina pentacamerata Zone ( $=A$. densa in Schlanger, Jackson, et al., 1976); they appear a little younger than the Nummulites assemblage. 
Assemblage (4), dated as late Eocene, occurs only at Site 318 in Cores 18 and 19 (Globigerinatheka semiinvoluta Zone, late Eocene). The only Nummulites yet recorded from the central Pacific occur in this interval.

At the other sites, the corresponding late Eocene interval is not recorded because of poor recovery (Site 315 ), because it was not cored (Site 165), or because it is missing (hiatus) (Site 316). However, at Site 165, representatives of Eocene assemblages (e.g., Discocyclina and Asterocyclina) are reworked in the late Oligocene (Core 3A). Discocyclinids were also recovered in piston cores taken close to the pedestal of the Line Islands, reworked in coarse foraminifer sands of Pleistocene age, during a cruise of the R/V Kana Keoki in the summer of 1979 (personal observation).

At Site 318 , a discocyclinid assemblage associated with frequent coralline algae and Sphaerogypsina occurs also in the earlier two planktonic-foraminifer zones of the middle Eocene (Cores 26 and 23).

Assemblages (5) and (6), of the early and possibly late Oligocene respectively, were not recovered from other drill sites. Post-Eocene species are recorded from Site 318; there Heterostegina sp. cf. H. suborbicularis and an unidentified Lepidocyclina occur in Core 10 and are attributed to the early Miocene. Beckmann (1976) stated that their occurrence did not conflict with the age inferred from the planktonic faunas. On the other hand, those two species could also be late Oligocene in age and be reworked in the Miocene.

Although faunas of Assemblages (5) and (6) are not recorded from the other sites, there is clear evidence that coarser layers occur at similar stratigraphic levels, but contain only reworked or undiagnostic faunas (Site 165, late Oligocene; Site 315, early and late Oligocene), or else are unfossiliferous and volcanogenic (Sites 316 and 165 , early Oligocene). At Hole 462 , Core 15 , a reworked, shallow-water fauna occurs together with relatively abundant volcanic elements. This level was not recorded at sites close to the Line Islands chain. It could instead be correlated with the volcaniclastic breccia containing coarse, shallow-water debris, including Lepidocyclina, as mentioned above, recorded at Site 318 , Core 10 , Section 1. This breccia, underlain by foraminifernannofossil chalk, is dated as early Miocene (Globorotalia kugleri Zone). Because the next core (Core 9) belongs to the upper part of the middle Miocene, a gap representing most of the early Miocene and lower part of the middle Miocene is hypothesized (Schlanger, Jackson, et al., 1976). In the absence of direct evidence of an early Miocene age, we suggest that the breccia was possibly deposited during the middle Miocene, just predating the pelagic ooze of Core 9 . If this interpretation is correct, then the occurrence of the coarse, shallow-water material of Hole 462 in the middle Miocene is not a local sedimentary feature, but has a wider significance.

Finally, Assemblage (7) and the associated volcanic ash recorded at Site 462 (Cores 5 and 6) could be correlated with the shallow-water assemblage described by Beckmann (1976) at Site 318, Core 2, dated as Pliocene/Pleistocene boundary.

\section{BIOPROVINCIAL AFFINITIES OF THE REEF-DERIVED FAUNAS}

Besides the interesting implications for tectonic and volcanic reconstruction of the Pacific Plate (see Schlanger and Premoli Silva, this volume), the reef faunas recovered at the Pacific drill sites provide information on the distribution of larger foraminifers, greatly increasing our knowledge about the early bioprovinces.

The oldest records (Cuneolina, orbitolinids, etc.), of mid-Cretaceous age, confirm the cosmopolitan character of the low-latitude foraminifer assemblages associated with rudistid reefs.

During the Late Cretaceous, as already pointed out by Beckmann (1976), the larger foraminifers of the central Pacific display great affinities with the CaribbeanCentral American province (van Gorsel, 1978). Pseudorbitoididae and Sulcoperculina, conspicuous elements of the Caribbean province, are the most important components of the faunas here described. They are associated with faunal elements, such as representatives of Lepidorbitoides evolutionary lineage, which according to van Gorsel (1978) should be restricted to the "Eurasian" bioprovince. Consequently, this genus has a much wider distribution than was previously thought, unlike the family Orbitoididae, which is not represented in our assemblages. Thus, during Late Cretaceous time, a bioprovince was differentiated in the central Pacific, characterized by the association of Pseudorbitoididae, Sulcoperculina, and Lepidorbitoides.

To explain the occurrence of elements from both bioprovinces, we have to assume that the direction of migration towards the Line and Marshall Islands areas was from both sides of the Pacific, from the east (Lepidorbitoides), and mainly from the west (Pseudorbitoididae and Sulcoperculina). Orbitoididae, which are present both in the west Pacific area (Papua; Glaessner, 1960) and in the Caribbean, have not been recorded from the central Pacific province.

The eastward migration of Lepidorbitoides is relatively easy to explain (many islands or "stepping stones" were probably available at that time in the western Pacific). The seemingly rapid westward migration of the Caribbean faunas suggests that the Caribbean and Line-Marshall Islands areas were much closer during the Cretaceous than they are today. It is well known that shallow-water faunas cannot easily migrate across a large, deep ocean, such as the present eastern Pacific, which would act as a barrier. Figure 5 presents a simplified paleogeographic reconstruction of the eastern Pacific at the end of the Cretaceous, based on magneticanomaly lineations (Pittman et al., 1974). The present Caribbean Plate is back-tracked close to those segments of the Pacific Plate where Line and Marshall Islands formed. If this reconstruction is correct, in Cretaceous time shallow "stepping stones" existed to permit a rapid colonization of the Line-Marshall Island areas by the Caribbean faunas.

During the Early Tertiary, the direction of the main faunal migration was reversed. Rapid ocean spreading in the eastern Pacific resulted in a rapid decrease of af- 


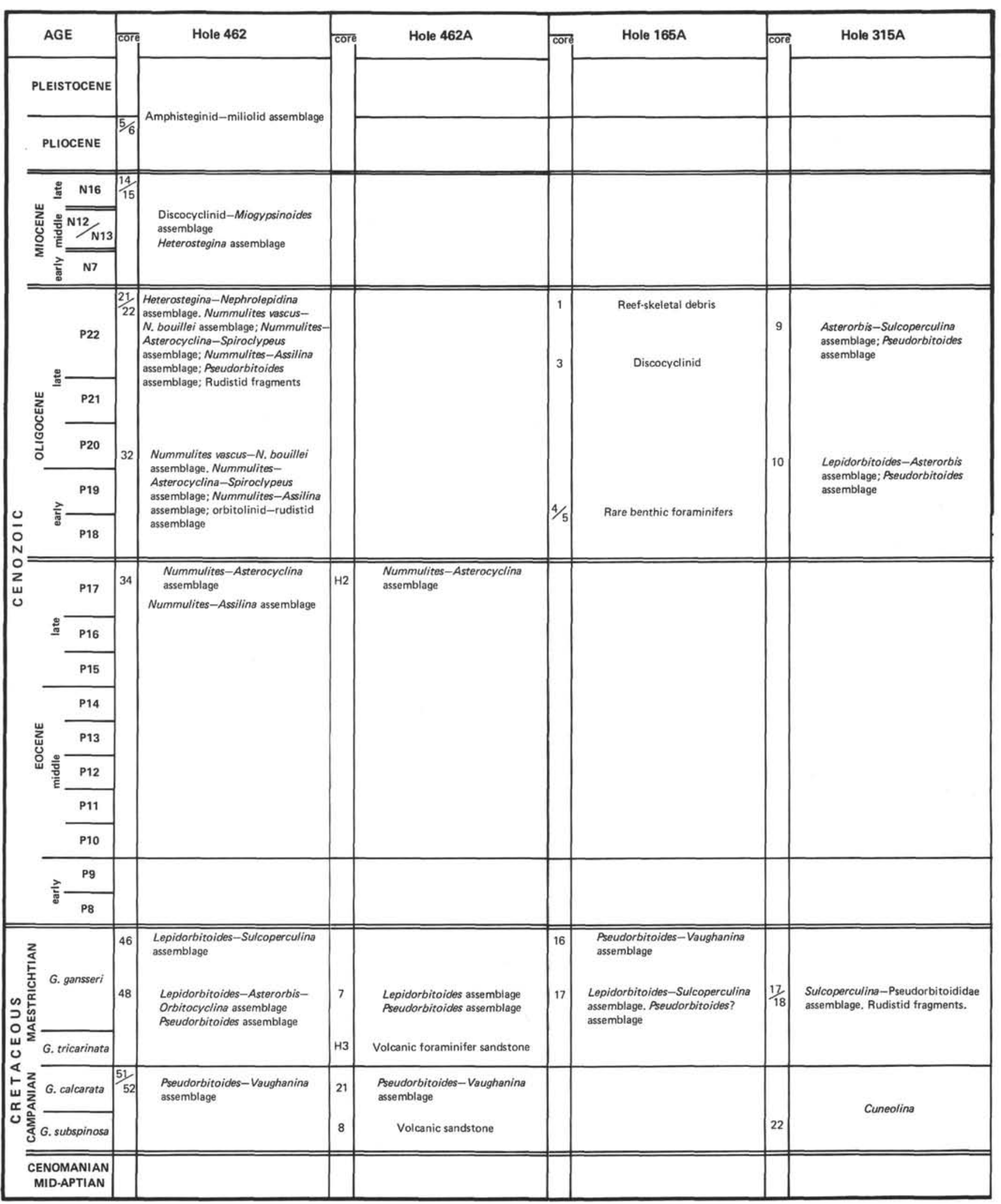

Figure 4. Distribution of shallow-water assemblages at the major DSDP Sites, Eniwetok drill hole, and Isakov Guyot (central Pacific), plotted against age and planktonic-foraminifer zones. Absolute age is after Hardenbol and Berggren (1978) and Berggren and Van Couvering (1972). Note that the late(?) Eocene assemblage comprehends middle and late Eocene assemblages. 


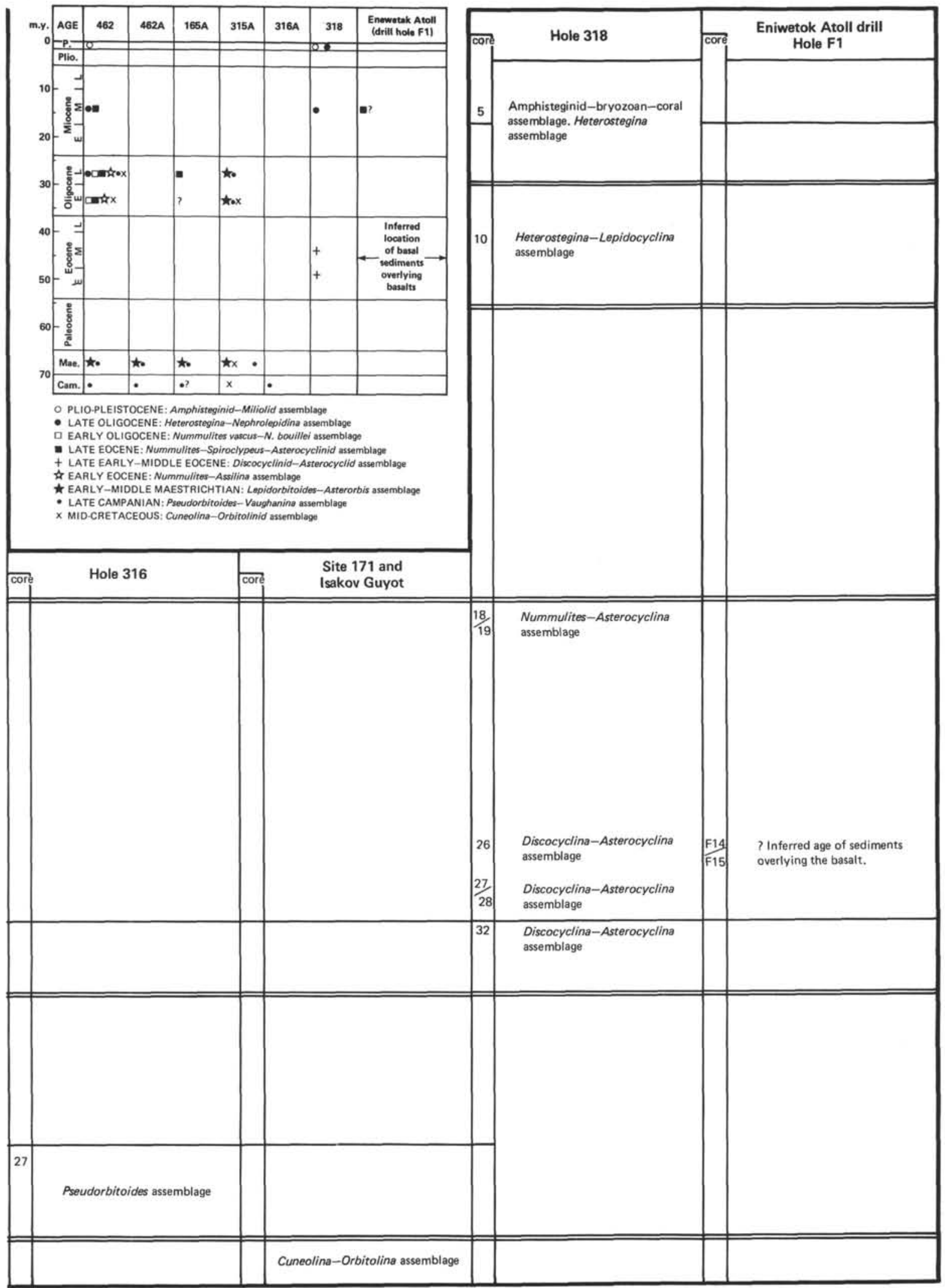

Figure 4. (Continued). 


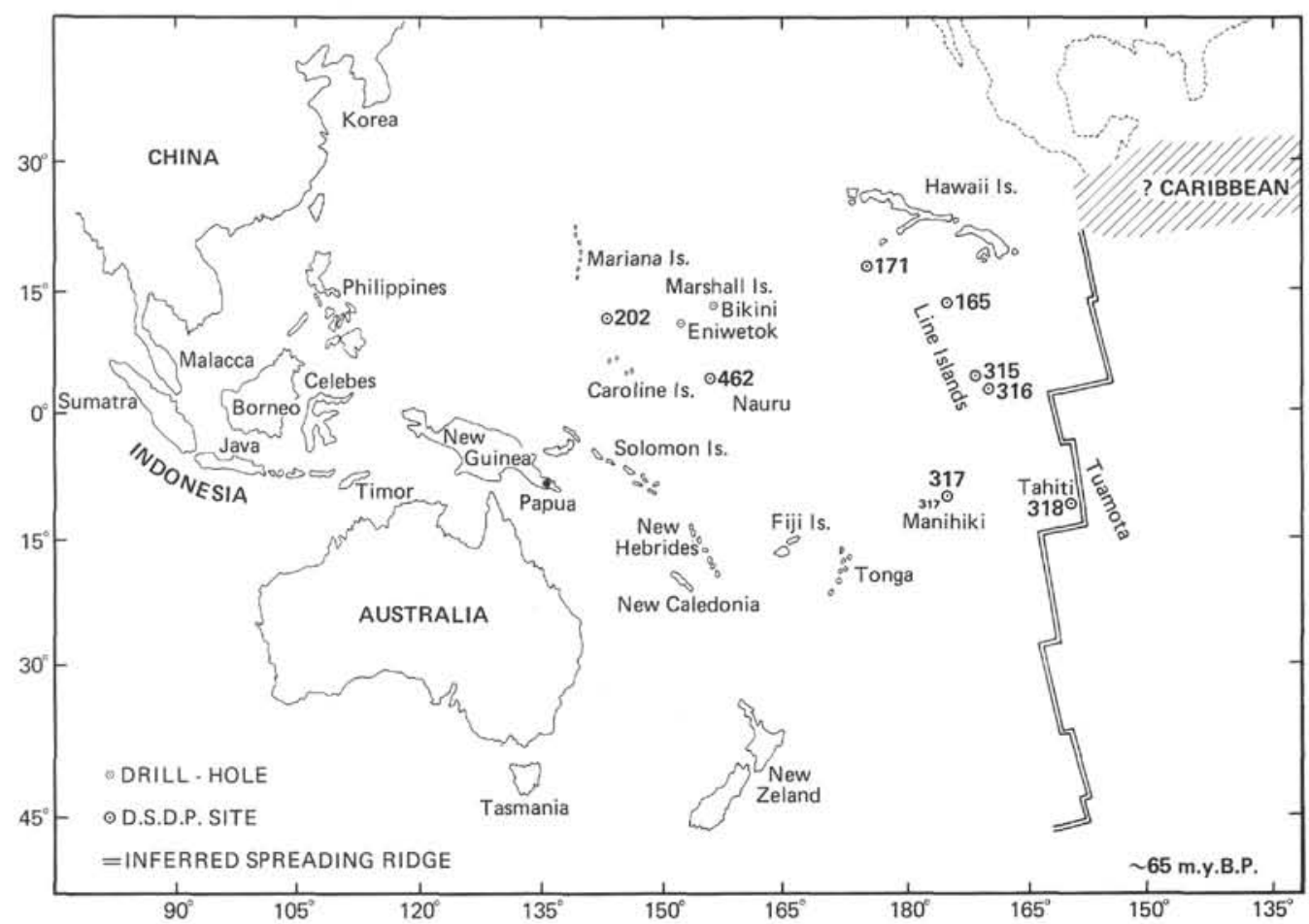

Figure 5. Simplified reconstruction of the eastern Pacific at the end of the Cretaceous ( $\sim 65$ m.y. ago), made by following the Caribbean hypothetically back-tracked westward. Note that Australia, New Guinea, etc., have been drawn in their present position. Although the Tuamotu Ridge is considered a Tertiary feature, Site 318 location was included. Asterisk in Papua indicates the westernmost occurrence of Pseudorbitoides israelskyi, a species characteristic of the Caribbean bioprovince during the Late Cretaceous.

finities with the Caribbean province. Only one element of the Caribbean faunas, Polylepidina (Adams, 1967), is surely recorded in the Marshall Island area during the middle Eocene; Polylepidina seems to have played the same role in the Tertiary as Lepidorbitoides did in the Cretaceous.

All the other foraminifer taxa are known from the Indo-Pacific region (Indonesia, Mariana Islands, etc.), and from the Tethys.

Discocyclinids are almost the only components of the early and middle Eocene faunas of the Tuamotu Ridge and Line Islands areas: they are particularly abundant at Tuamotu, much rarer at the Line Islands. In the Marshall Islands area, foraminifer assemblages are dominated by nummulitids: Nummulites and Assilina in the early Eocene, Nummulites alone in the late Eocene and early Oligocene. All the identified forms are typically Tethyan elements, except for Nummulites sp. cf. $N$. bagelensis, described from the Indo-Pacific region, which is however a possible junior synonym of $N$. javanus or N. perforatus(?) (Adams, 1970). Only late in the Eocene did Nummulites and Heterostegina colonize the Tuamotu area.

It appears that the late Eocene was when the Tethyan and Indo-Pacific provinces (Adams, 1970) had their maximum expansion, that is to say, when Nummulites sp. aff. $N$. variolarius reached the Tuamotu area to the east.
Other nummulitids (Operculina, Heterostegina, Spiroclypeus), mainly described from the Indo-Pacific region, are again among the components of late Eocene and Oligocene assemblages in the Marshalls area, along with rare lepidocyclinids. Very few representatives of some of these genera migrated so far east as the Tuamotu area. If our interpretation of the age of Lepidocyclina and Heterostegina at Site 318 (Core 10) is correct, such migration occurred during the late Oligocene.

We did not record Biplanispira and Pellatispira, previously described at Eniwetok (Cole, 1957) and widespread in the Indo-Pacific region.

\section{PALEOGEOGRAPHIC IMPLICATIONS}

The shallow-water skeletal debris recorded in the central and western Pacific from the Pacific Plate testifies to the presence during the Cretaceous and Cenozoic of edifices rising from the sea floor which reached the euphotic zone and rested close to the surface (sea level) long enough to be colonized by shallow-water faunas and floras. This process was repeated several times.

The high stratigraphic resolution of larger foraminifers, even if they are scattered and randomly distributed throughout the various sequences, allowed us to assign a precise age to those events. There is evidence for reefs or shallow carbonate platforms during the following time intervals (from older to younger): 
1) Mid-Cretaceous, on the occurrence of Cuneolina and orbitolinids (Line Islands, Mid-Pacific Mountains, Nauru Basin, Pacific Seamounts); plant remains, recovered in Hole 462A, Core 40, Section 1, and dated on the basis of radiolarians as Aptian-Albian, indicate the existence of islands;

2) Late Campanian, on the basis of Pseudorbitoides assemblages (Line Islands, Nauru Basin);

3) Middle to late Maestrichtian, and possibly early Maestrichtian, on the basis of Lepidorbitoides-Asterorbis assemblages (Line Islands, Nauru Basin);

4) Early Eocene, on the basis of a NummulitesAssilina assemblage (Nauru Basin);

5) Late early to early middle Eocene, on the basis of a Discocyclina-Asterocyclina assemblage (Tuamotu Ridge), associated with planktonic foraminifers of that age;

6) Middle Eocene, on the basis of the occurrence of Polylepidina antillea and $N$. sp. cf. $N$. bagelensis (Nauru Basin);

7) Late Eocene, on the basis of Nummulites-Asterocyclina-Spiroclypeus assemblages (Nauru Basin, Tuamotu Ridge);

8) Early Oligocene, on the basis of a Nummulites vascus or $N$. bouillei assemblage (Nauru Basin);

9) Late Oligocene, on the basis of Heterostegina borneensis-Nephrolepidina sumatrensis assemblages, probably associated with Miogypsinoides ubaghsi and $M$. grandipustula (Nauru Basin, Tuamotu Ridge?).

Moreover, the occurrence of transported shallowwater skeletal debris which accumulated as sediments at oceanic depths permits precise dating of erosional events by larger-foraminifer faunas and associated and/ or overlying-underlying planktonic faunas (foraminifers and radiolarians) and floras (calcareous nannoplankton). The main erosional events were:

1) Late Campanian, with the beginning of volcaniclastic sedimentation (Nauru Basin, Line Islands, MidPacific Mountains);

2) Middle(?)-late Maestrichtian (Nauru Basin, Line Islands);

3) Late early to early middle Eocene (Tuamotu Ridge);

4) Late Eocene (Line Islands?, Nauru Basin?, Tuamotu Ridge);

5) Early late Oligocene (Nauru Basin, Line Islands);

6) Late Oligocene (Nauru Basin, Line Islands);

7) Middle Miocene (Nauru Basin, Tuamotu Ridge?);

8) Pleistocene (Nauru Basin, Tuamotu Ridge).

Minor erosional events are recorded throughout the Oligocene part of the sequence at Hole 462 (Nauru Basin).

At some stratigraphic levels, shallow-water skeletal debris is associated with abundant volcanic material, consisting of glass (fresh to altered), rock fragments, and rare ash. This association suggests that the volcanic activity provided the necessary pedestals on which reefs and carbonate platforms could grow (see Schlanger and Premoli Silva, this volume). The shallow-water debris provides a basis for dating the volcanic activity; the best estimates for the central Pacific are:
1) Early(?)-late Campanian, based on the thick volcaniclastic sequence, containing in its upper portion the late Campanian larger foraminifers; this phase is widespread in the Line Islands, Nauru Basin, and Mid-Pacific Mountains;

2) Early(?)-middle Eocene, based on basalts recovered from the bottom of the Eniwetok drill hole (Marshall Islands) and dated at about 49 m.y.; of the same age is the beginning of volcanism in the Tuamotu Ridge, where it continued during at least part of the middle Eocene (Schlanger, Jackson, et al., 1976);

3) Middle Miocene(?) (Nauru Basin [Core 15], and Tuamotu);

Volcanic material occurs also in late(?) Eocene, early late, and late Oligocene sediments. However, this material is interpreted as being reworked along with the associated shallow-water debris, and is not therefore indicative of additional volcanic activity.

\section{ACKNOWLEDGMENTS}

The authors would like to thank the Deep Sea Drilling Project-for inviting one of them (I.P.S.) to participate aboard the Glomar Challenger on Leg 61 to the Nauru Basin.

The authors are greatly indebted to C. G. Adams, British Museum (Natural History), London, whose large experience and critical advice on taxonomy and distribution of larger foraminifers have been fundamental in the improvement of this paper; to J. P. Beckmann, ETH-Zurich, for helpful discussion concerning taxonomic problems of larger foraminifers and for having made available his collection of shallow-water debris from Leg 33 sites; to S. H. Frost, Gulf Research and Development Co., Houston, for his determinations of invertebrate fragments, and for his helpful advice on Caribbean foraminifer faunas; to R. Cifelli, for facilities during the visit of I.P.S. to the Smithsonian, Washington, D.C., where Cole's collections are deposited.

The scanning electron micrographs were made by Agostino Rizzi, Centro per la Stratigrafia delle Alpi Centrali, C.N.R., Milano. Financial support was provided by the Ministry of Public Education, through Grant MPI/79 to Prof. C. Rossi Ronchetti, Istituto di Paleontologia, Università di Milano.

The paper was critically revised by M. B. Cita, University of Milan, and C. G. Adams, British Museum (Natural History), London.

\section{REFERENCES}

Adams, C. G., 1965. The foraminifera and stratigraphy of the Melinau Limestone, Sarawak, and its importance in Tertiary correlation. Quat. J. Geol. Soc. London, 121:283-338.

1967. Tertiary foraminifera in the Tethyan, American, and Indo-Pacific Provinces. System. Ass. Publ., 7:195.

1970. A reconsideration of the East Indian letter classification of the Tertiary. Bull. Brit. Mus. (Nat. Hist.), Geol., 19(3):87.

Beckmann, J. P., 1976. Shallow water foraminifers and associated microfossils from Sites 315, 316 and 318, DSDP Leg 33. In Schlanger, S. O., Jackson, E. D., et al., Init. Repts. DSDP, 33: Washington (U.S. Govt. Printing Office), 467.

Blondeau, A., 1980. Les etages Français et leur stratotype: Lutetien. Mém. B.R.G.M., 109:211-223.

Brönnimann, P., 1940-1942. Über die tertiären Orbitoididen und die Miogypsiniden von Nordwest-Marokko. Schweiz. Paläont. Abh., 63.

1954. Upper Cretaceous orbitoidal foraminifera from Cuba. II. Vaughanina Palmer. Contr. Cush. Found. Foram. Res., 5:91.

, 1955. Upper Cretaceous orbitoidal foraminifera from Cuba. III. Pseudorbitoides Douvillé. Contr. Cush. Found. Foram. Res., 6:57.

1957. Morphology and stratigraphic significance of Pseudorbitoides israelskyi Vaughan and Cole. Eclogae Geol. Helv., 50:582. 
Caro, Y., Luterbacher, H. P., Perch-Nielsen, K., et al., 1975. Zonation à l'aide de microfossiles pélagiques du Paléocène supérieur et de l'Eocène inférieur. Bull. Soc. Géol. France, 17(2):125.

Caudri, C. M. B.,1974. The larger foraminifera of Punta Mosquito, Margarita Island, Venezuela. Verhandl. Naturf. Ges. Basel, 84(1): 293-318.

1975. Geology and paleontology of Soldado Rock, Trinidad, (West Indies). Eclogae Geol. Helv., 68(3):533-589.

Cole, W. S., 1957. Larger foraminifera from Eniwetok Atoll drill holes. U.S. Geol. Surv. Prof. Paper, 260-V:754.

1958. Larger foraminifera. Geology of Saipan-Mariana Islands. U.S. Geol. Surv. Prof. Paper, 280-I:321.

1960. Revision of Helicostegina, Helicolepidina and Lepidocyclina (Polylepidina). Contr. Cush. Found. Foram. Res., 11(2):57-63.

1963. Tertiary larger foraminifera from Guam. U.S. Geol. Surv. Prof. Paper, 403-E:12

1969. Larger foraminifera from deep sea drill holes on Midway Atoll. U.S. Geol. Surv. Prof. Paper, 680-C:C-1

Dilley, F. C., 1973. Cretaceous larger foraminifera. In Hallam, A. (Ed.), Atlas of Paleobiogeography, p. 403.

Doornink, H. W., 1932. Tertiary Nummulitidae from Java. Verh. Geol. Mijnb. Gen. Ned. Kd. Geol. Series, 9:267-315.

Drooger, C. W., 1963. Evolutionary trends in the Miogypsinidae. Evolutionary Trends in Foraminifera: New York (Elsevier), pp. 315-349.

Ellis, B. F., and Messina, A. R., 1940. Catalogue of Foraminifera. 1965. Catalogue of Index Foraminifera, v. 1/2/3.

Eva, A. N., 1980. Pre-cyclical chamber arrangement in the foraminiferal genus Polylepidina Vaughan, 1924. Micropaleont., 26:90-94.

Frost, S. H., 1974. Evolution in the Sulcoperculina-Sulcorbitoides foraminiferal lineage, Upper Cretaceous, Puerto Rico. Verhandl. Naturf. Ges. Basel, 84(1):265-279.

Glaessner, M. F., 1960. Upper Cretaceous larger foraminifera from New Guinea. Sci. Repts. Tohoku Univ., Ser. 2 (Geol.) Spec., 4:37.

Haak, R., and Postuma, J. A., 1975. The relation between the tropical planktonic foraminiferal zonation and the Tertiary Far East letter classification. Geol. en. Mijnbovw, 54(34):195.

Hanzawa, S., 1957. Cenozoic foraminifera of Micronesia. Geol. Soc. Am. Mem., 66.

1962. Upper Cretaceous and Tertiary three-layered larger foraminifera and their allied forms. Micropaleont., 8:129.

Heezen, B. C., MacGregor, I. D., et al., 1973. Init. Repts. DSDP, 20: Washington (U.S. Govt. Printing Office).

Herb, R., and Hekel, H., 1957. Nummuliten aus dem Obereocaen von Possagno. Monografia Micropaleontologica sul Paleocene e l'Eocene di Possagno, Provincia di Treviso, Italia. Schweiz. Palaont. Abh., 97:113.

Kapellos, C. Ch., 1973. Biostratigraphie des Gurnigelflysches. Schweiz. Paläont. Abh., 96:75.

Lanterno, E., and Roveda, V., 1957. Sur les couples des Nummulites $N$. incrassatus(B)-N. ramondiformis(A) et $N$. vascus(B)-N. boucheri(A). Arch. Sci., 10(2):143.

Larson, R. L., Moberly, R., et al., 1975. Init. Repts. DSDP, 32: Washington (U.S. Govt. Printing Office).

Loeblich, A. R., Jr., and Tappan, H., 1964. Treatise on Invertebrate Paleontology. Protista. C.2.

McGowran, B., 1979. The Tertiary of Australia: foraminiferal overview. Mar. Micropaleont., 4(3):235.

Neumann, M., 1958. Révision des Orbitoididés du Crétacé et de l'Eocène en Aquitaine occidentale. Mém. Soc. Géol. France, 83:70.

Pavlovec, R., 1966. Evolution of the species Nummulites problematicus (Tellini) and its vertical extension. Bull. Sc. Cons. Acad. RSF Yougoslavie, Sec. A, 11(1):4.

Pittman, W. C., Larson, R. L., and Herron, E. M., 1974. Magnetic Lineations of the Ocean: Boulder (Geol. Soc. Am.). [maps]

Renz, H. H., 1955. Some Upper Cretaceous and lower Tertiary foraminifera from Aragua and Guarico, Venezuela. Micropaleontol., 1(1):56.

Roveda, V., 1970. Revision of Nummulites (Foraminiferida) of the $N$. fabiani-fichteli group. Riv. Ital. Paleont. Strat., 76(2):292.

Schaub, H., 1951. Strtigraphie und Paläontologie des Schlierenflysches. Schweiz. Palaont. Abh., 68:108.
1961. Acerca de algunas Nummulites y Assilinas de la Monografia y Colleccion de D'Archiac. Notas Comuns. Inst. Geol. Min. Espana, 62:171.

1963. Über einige Entwicklungsreihen von Nummulites und Assilina und ihre stratigraphische Bedeutung. Evolutionary Trends in Foraminifera, p. 282.

Schlanger, S. O., Jackson, E. D., et al., 1976. Init. Repts. DSDP, 33: Washington (U.S. Govt. Printing Office).

Tan, S. H., 1932. On the genus Cycloclypeus Carpenter. Pt. I and an appendix on the Heterosteginas of Tjimanggoe, Java. Wet. Meded. Dienst. Mijnb. Ned-Ost-Indie, 19:3.

Todd, R., 1957. Smaller foraminifera. Geology of Saipan, Mariana Islands. U.S. Geol. Surv. Prof. Paper, 280-H:265.

1954. Smaller foraminifera from Bikini drill holes. U.S. Geol. Surv. Prof. Paper, 260-N.

1960. Smaller foraminifera from Eniwetok drill holes. U.S. Geol. Surv. Prof. Paper, 354-H:799.

1961. Foraminifera from Onotoa Atoll, Gilbert Islands. U.S. Geol. Surv. Prof. Paper, 260-X:171.

1964. Planktonic foraminifera from deep-sea cores off Eniwetok Atoll. U.S. Geol. Surv. Prof. Paper, 260-CC:1067.

van Gorsel, J. J., 1975. Evolutionary trends and stratigraphic significance of the Late Cretaceous Helicorbitoides-Lepidorbitoides lineage. Utrecht Micropaleont. Bull., 12:1.

1978. Late Cretaceous orbitoidal foraminifera. In Hedley, R. H., and Adams, C. G. (Eds.), Foraminifera (Vol. 3): London (Acad. Press), 1-120.

van Hinte, J. E., 1976. A Cretaceous time scale. Bull. Am. Assoc. Petrol. Geol., 60:498.

Winterer, E. L., 1977. Carbonate sediments on the flanks of seamount chains. In Andersen, N. R., and Malahoff, A. (Eds.), The Fate of Fossil Fuel $\mathrm{CO}_{2}$ in the Oceans: New York (Plenum), pp. 693-716.

Winterer, E. L., Ewing, J. I., et al., 1973. Init. Repts. DSDP, 17: Washington (U.S. Govt. Printing Office).

\section{APPENDIX \\ Fossil List}

Most of the larger-foraminifer taxa encountered in Hole 462 previously have not been described or illustrated from deep-sea sediments. Poor preservation often has made identification difficult; they are all illustrated and only tentatively identified.

The classification used in the present paper is that by Loeblich and Tappan (1964) at least at the family level. For the nummulitids, Cushman's classification (1949) is followed. Species will be described in a separate paper now in preparation.

Family Orbitolinidae

Dictyconus sp. aff. D. saipanensis Cole, 1958. See: Cole, 1957, p. 329 , pl. 101 , fig. 3 .

Family Rotaliidae

Pararotalia sp. aff. P. byramensis (Cushman), 1922. See: Ellis and Messina, 1940 , et seq.

Family Nummulitidae

Assilina leymeriei (d'Archiac and Haime), 1853. See: Schaub, 1951 , p. 178 , pl. 3 , figs. $1-8$; pl. 4 , figs. $1-16$.

Nummulites sp. cf. N. bagelensis (Veerbeck), 1891. See: Ellis and Messina, 1940 et seq.; Doornick, 1932, p. 277, pl. 2, figs. 3-9.

Nummulites bouillei (de la Harpe), 1879. See: Herb et al., 1975, p. 125 , pl. 1, figs. 9-11.

Nummulites burdigalensis minor (de la Harpe), 1926. See: Schaub, 1951 , p. 118 , pl. 3 , figs. 8-9; text figs. 89-91.

Nummulites partschi (de la Harpe), 1880. See: Schaub, 1951, p. 140 , pl. 4 , figs. 4-17.

Nummulites pernotus Schaub, 1951. See: Schaub, 1951, p. 108, pl. 1, figs. 7-12; text figs. 59-61.

Nummulites problematicus (Tellini), 1908. See: Roveda, 1970, p. 277 , pl. 25, figs. 10-15.

Nummulites rotularius Deshayes, 1838. See: Schaub, 1951, p. 125, figs. 111-116. 
Nummulites sp. aff. $N$. variolarius (Lamarck), 1804. See: Beckmann, 1976 , p. 469 , pl. 7 , figs. $10-12$; pl. 8 , figs. $7-8,10-11$. Nummulites vascus (Joly and Leymerie), 1848. See: Lanterno and Roveda, 1957, p. 157, pl. 2, figs. 1-10.

Operculina sp. cf. O. complanata (Defrance), 1822. See: Ellis and Messina, 1940 et seq.

Operculina eniwetokensis Cole, 1957. See: Cole, 1957, p. 232, pl. 103 , figs. $15-23$.

Operculina subformai (Provale), 1908. See: Cole, 1963, p. E16, pl. 2 , figs. $1-4$.

Sulcoperculina cubensis (Palmer), 1934. See: Ellis and Messina, 1940 , et seq.

Sulcoperculina vermunti (Thiadens), 1937. See: Beckmann, 1976, p. 469 , pl. 1, figs. 8-9; pl. 2, figs. 9-10.

Heterostegina borneensis Van der Vlerk, 1929. See: Cole 1958, p. 331 , pl. 95 , figs. $16-20$.

Heterostegina saipanensis Cole 1953. See: Cole, 1958, p. 331, pl. 102 , figs. $17-19$.

Heterostegina suborbicularis (d'Orbigny), 1826. See: Cole 1957, p. 762 , pl. 235 , figs. $14-20$.

Spiroclypeus sp. cf. S. albapustula Cole, 1957. See: Cole, 1957, p. 762, pl. 238, figs. $7,13,18$.

Spiroclypeus higginsi Cole, 1939. See: Cole, 1957, p. 763, pl. 239, figs. 11-12, 14.

Spiroclypeus sp. cf. vermicularis Tan, 1937. See: Cole, 1957, p. 764 , pl. 238 , figs. $1-6,8-12$.

Family Miogypsinidae

Miogypsinoides grandipustula (Cole), 1954. See: Cole, 1954, p. 602 , pl. 221 , figs. $2-4,19-22$; pl. 222 , figs. $12-14$.

Miogypsinoides ubaghsi Tan, 1936. See: Cole, 1957, p. 603, pl. 221, figs. 5-9; pl. 222, figs. 13-15.

Family Lepidorbitoididae

Lepidorbitoides bisambergensis (Jaeger), 1914. See: van Gorsel, 1978, p. 46 , fig. 16 d, text-fig. 15 .

Lepidorbitoides minor (Schlumberger), 1902. See: van Gorsel, 1978, p. 46, fig. 16e, text-fig. 15.
Lepidorbitoides socialis (Leymerie), 1851. See: van Gorsel, 1978, p. 46 , fig. $16 \mathrm{f}$, text-fig. 15 .

Orbitocyclina minima (Douvillé), 1927. See: van Gorsel, 1978, p. 55 , fig. 18.

Asterorbis cubensis Palmer, 1934. See: Ellis and Messina, 1940, et seq.

Asterorbis havanensis Palmer, 1934. See: Beckmann, 1976, p. 469, pl. 1, figs. 3, 5, 6 .

Asterorbis rooki Vaughan and Cole, 1932. See: Ellis and Messina 1940 et seq.

Family Discocyclinidae

Asterocyclina malladai Gómez Llueca, 1927. See: Ellis and Messina, 1940, et seq.

Asterocyclina matanzensis Cole, 1957. See: Cole, 1957, p. 350, pl. 117, figs. 6-10; pl. 118, figs. 9-18.

Asterocyclina penuria Cole, 1957. See: Cole, 1957, p. 350, pl. 116, figs. 1-10.

Family Lepidocyclinidae

Lepidocyclina (Eulepidina) sp. cf. L. ephippioides (Jones and Chapman), 1900. See: Ellis and Messina, 1965.

Lepidocyclina (Nephrolepidina) sumatrensis (Brady), 1953. See: Cole, 1953, p. 32, pl. 10, fig. 7, pl, 11, figs. 4, 5.

Polylepidina antillea (Cushman), 1919. See: Ellis and Messina, 1940 et seq.; Caudri, 1974 , p. 310 , pl. 8, figs. 6, 7.

Polylepidina? sp. aff. $P$. paucispira Barker and Grimsdale, 1936. See: Ellis and Messina, 1940, et seq.

Family Pseudorbitoididae

Pseudorbitoides israelskyi Vaughan and Cole, 1932. See: Beckmann, 1976, p. 469, pl. 1, figs. 1, 2, 4: pl. 4, figs. 1-9.

Vaughanina cubensis Palmer, 1934. See: Bronnimann, 1954, p. 91, pl. 18, figs. 1-4.

Vaughanina jordanae Brönnimann, 1958. See: Ellis and Messina, 1965. 

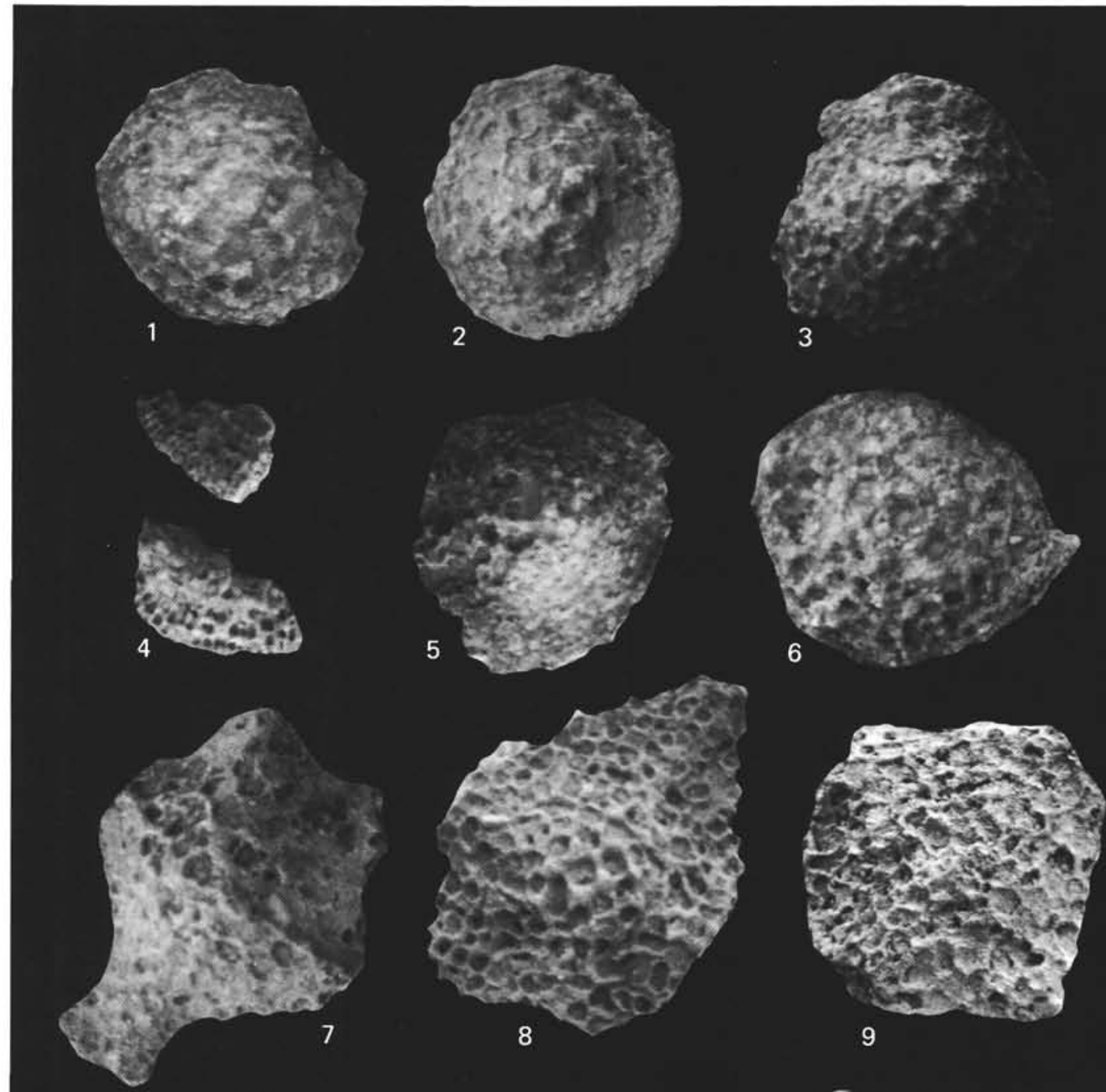

8

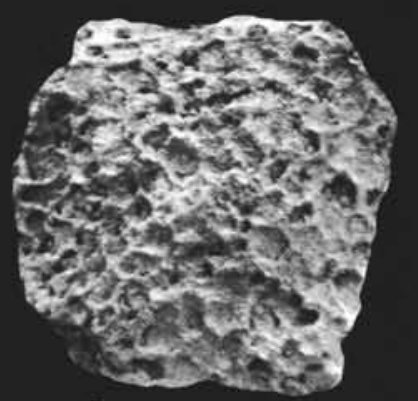

9
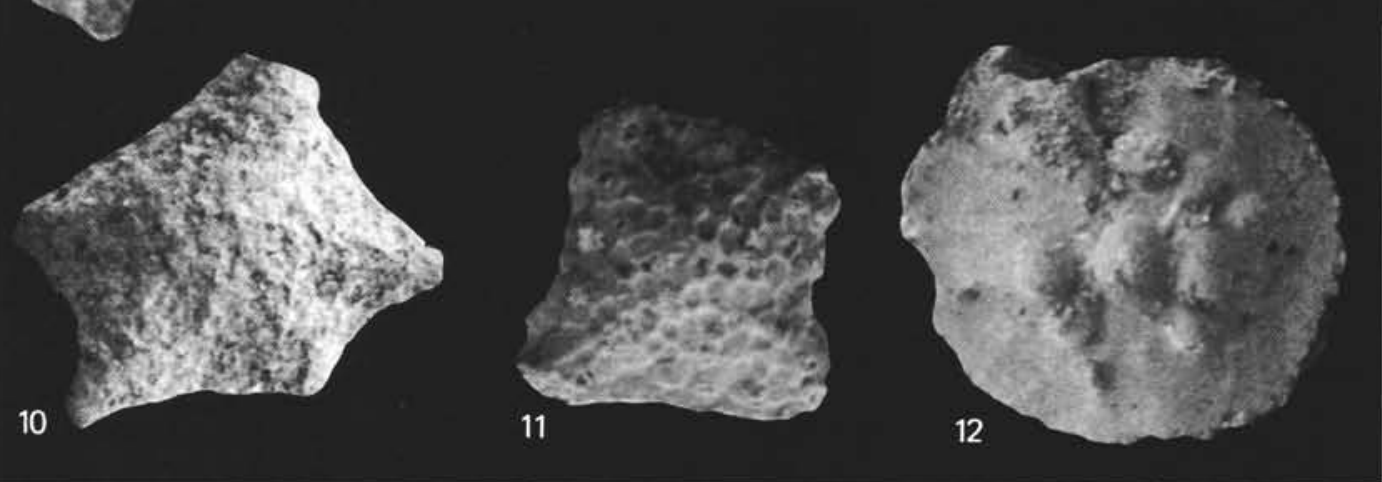

Plate 1. Photomicrographs.

Figure 1. Vaughanina cubensis Palmer. Leg 61, Site 462, Core 51-3, $91-96 \mathrm{~cm}$, late Campanian. External view, $\times 40$.

Figure 2. Vaughanina cubensis Palmer. Leg 61, Site 462, Core 51-3, 44-47 cm, late Campanian. External view, $\times 40$.

Figure 3. Vaughanina sp. Leg 61 , Site 462 , Core $52-1,98-101 \mathrm{~cm}$, late Campanian. External view, $\times 40$.

Figure 4. Vaughanina cubensis Palmer. Leg 61. Site 462, Core 52-1, 98-101 cm, late Campanian. External view, $\times 40$.

Figure 5. Vaughanina cubensis Palmer. Leg 61, Site 462, Core 51-3, 91-96 cm, late Campanian. External view, $\times 40$.

Figure 6. Vaughanina cubensis Palmer. Leg 61, Site 462, Core 51-3, 44-47 cm, late Campanian. External view, $\times 45$.
Figure 7. Asterorbis rooki Vaughan and Cole. Leg 61, Site 462, Core 48-2, 78-81 cm, middle Maestrichtian. External view, $\times 40$.

Figure 8. Asterorbis rooki Vaughan and Cole. Leg 61, Site 462, Core $48-2,78-81 \mathrm{~cm}$, middle Maestrichtian. External view, $\times 45$.

Figure 9. Asterorbis havanensis Palmer. Leg 61, Site 462. Core 48-1, $11-13 \mathrm{~cm}$, middle Maestrichtian. External view, $\times 45$.

Figure 10. Asterorbis cubensis Palmer. Leg 61. Site 462, Core 48 soup, middle Maestrichtian. External view, $\times 40$.

Figure 11. Asterorbis havanensis Palmer. Leg 61, Site 462, Core 48 soup, middle Maestrichtian. External view, $\times 40$.

Figure 12. Sulcoperculina cubensis Palmer. Leg 61, Site 462, Core 48$2,78-81 \mathrm{~cm}$, middle Maestrichtian. External view, $\times 50$. 


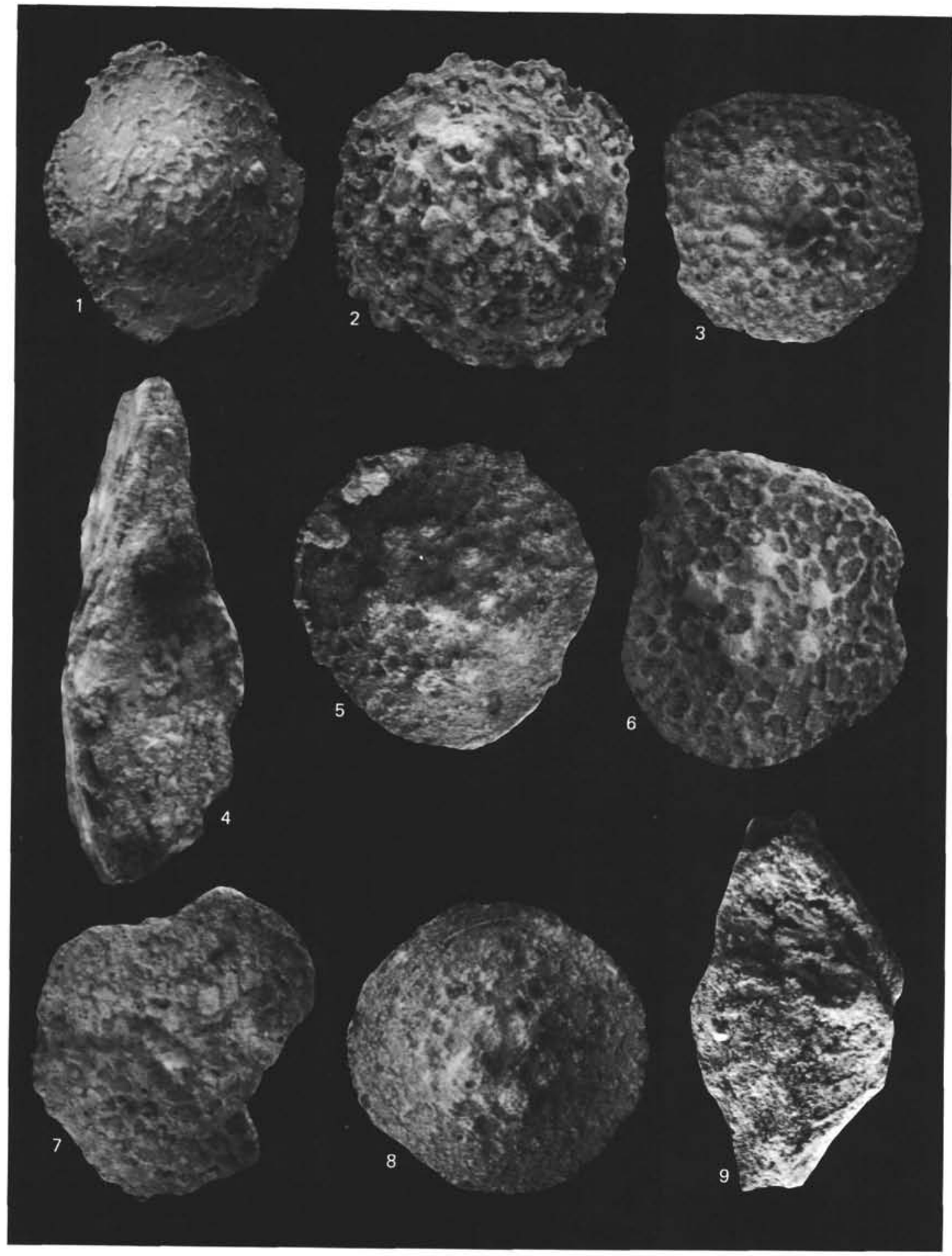

Plate 2. Photomicrographs.

Figure 1. Vaughanina sp. Leg 61, Site 462, Core 52-1, 98-101 cm, late Campanian. External view, $\times 46$.

Figure 2. Vaughanina sp. Leg 61, Site 462, Core 52-1, 98-101 cm, late Campanian. External view, $\times 55$.

Figure 3. Vaughanina cubensis Palmer. Leg 61, Site 462, Core 51-3, $44-47 \mathrm{~cm}$, late Campanian. External view, $\times 46$.

Figure 4. Vaughanina cubensis Palmer. Leg 61, Site 462, Core 51-3, 91-96 cm, late Campanian. Axial section of broken specimen, $\times 92$.
Figure 5. Vaughanina cubensis Palmer. Leg 61, Site 462, Core 51-3, 91-96 cm, late Campanian. External view, $\times 55$.

Figure 6. Vaughanina jordanae Brönnimann. Leg 61, Site 462, Core 51-3, 91-96 cm, late Campanian. External view, $\times 46$.

Figure 7. Vaughanina cubensis Palmer. Leg 61, Site 462. Core 51-3, 91-96 cm, late Campanian. External view, $\times 46$.

Figure 8. Vaughanina cubensis Palmer. Leg 61, Site 462, Core 51-3, 44-47 cm, late Campanian. External view, $\times 55$.

Figure 9. Sulcoperculina sp. Leg 61, Site 462, Core 48-1, 11-13 cm, middle Maestrichtian. Side view, $\times 64$. 

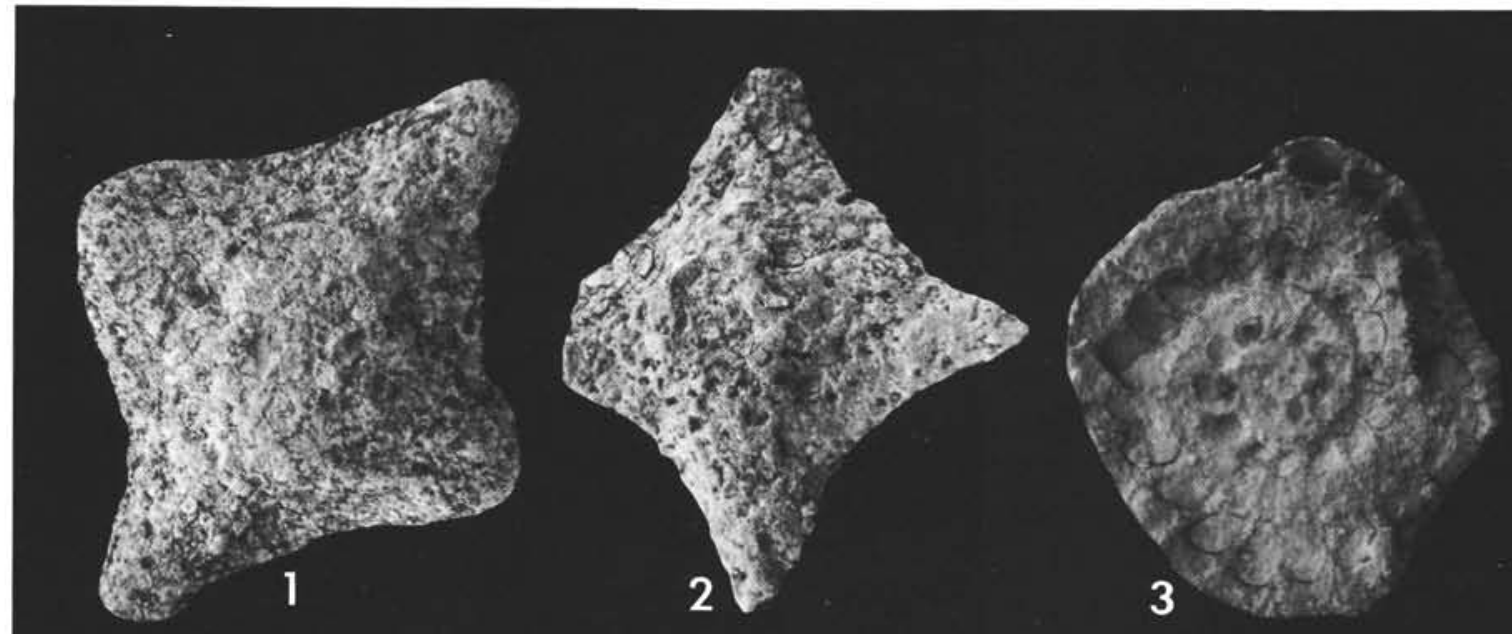

4

5
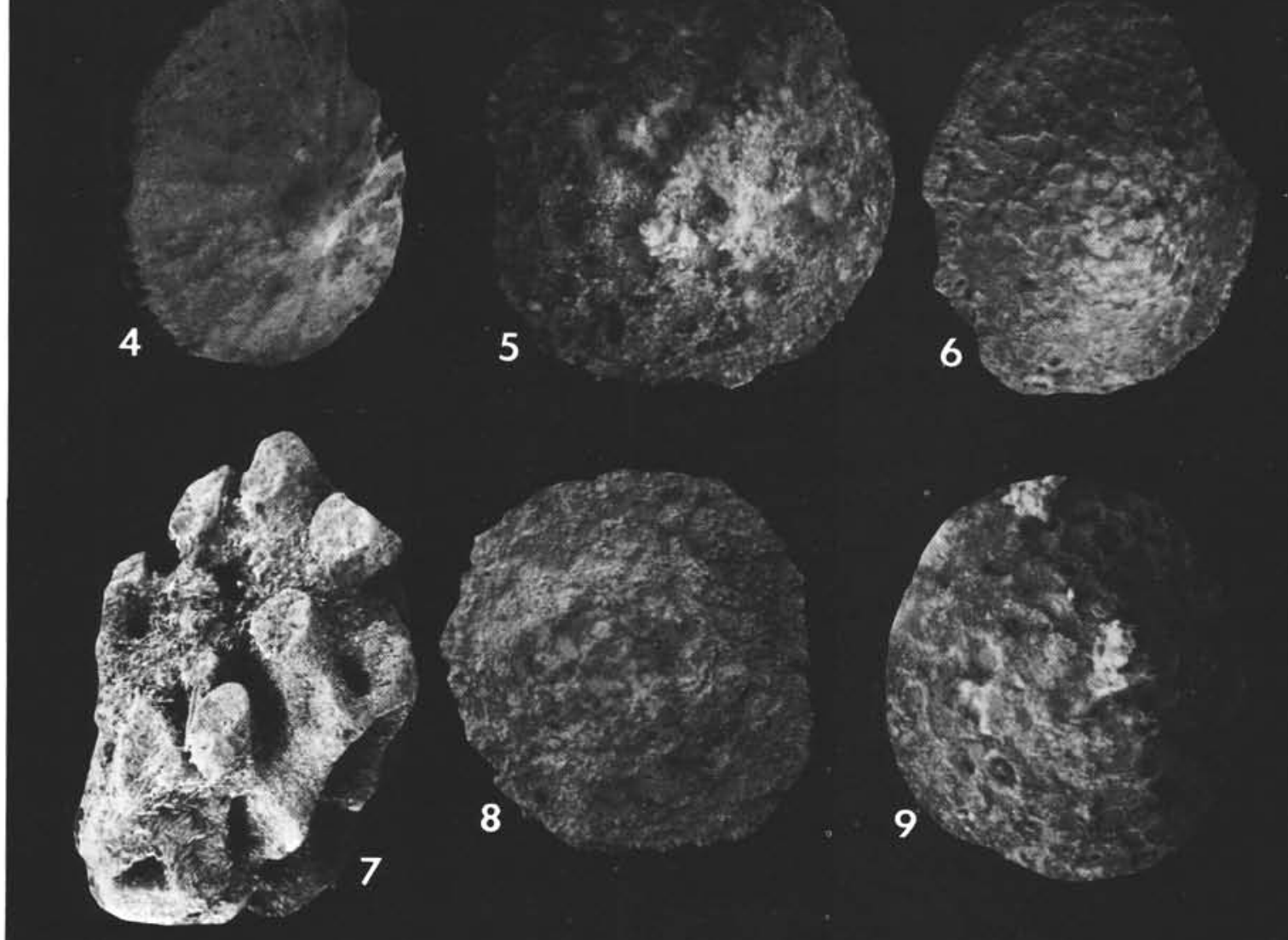

W.

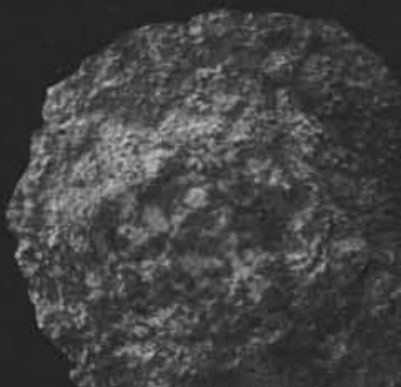

8

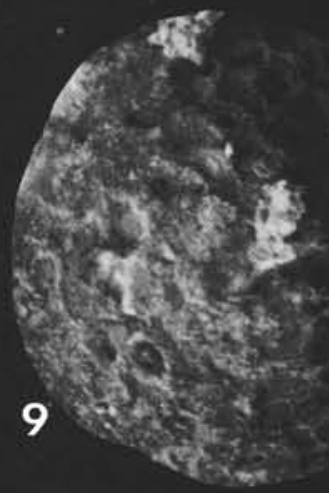

Plate 3. Photomicrographs.

Figure 1. Asterorbis havanensis Palmer. Leg 61, Site 462, Core 48 soup, middle Maestrichtian. External view, $\times 23$.

Figure 2. Asterorbis havanensis Palmer. Leg 61, Site 462, Core 48 soup, middle Maestrichtian. External view, $\times 23$.

Figure 3. Sulcoperculina vermunti Thiadens. Leg 61, Site 462, Core 48-2, 78-81 cm, middle Maestrichtian. Spiral section of broken specimen, $\times 45$.

Figure 4. Sulcoperculina vermunti Thiadens. Leg 61, Site 462, Core $48-2,78-81 \mathrm{~cm}$, middle Maestrichtian. Side view, $\times 45$.
Figure 5. Vaughanina jordanae Brönnimann. Leg 61, Site 462, Core 51-3, 91-96 cm, late Campanian. External view, $\times 27$.

Figure 6. Vaughanina cubensis Palmer. Leg 61, Site 462, Core 51-3, 91-96 cm, late Campanian. External view, $\times 45$.

Figure 7. Fragment of Axopora? Leg 61, Site 462, Core 22-1, 69-71 $\mathrm{cm}$, late Oligocene, $\times 23$.

Figure 8. Vaughanina cubensis Palmer. Leg 61, Site 462, Core 51-3, 44-47 cm, late Campanian. External view, $\times 45$.

Figure 9. Vaughanina cubensis Palmer. Leg 61, Site 462, Core 51-3, $91-96 \mathrm{~cm}$, late Campanian. External view, $\times 45$. 


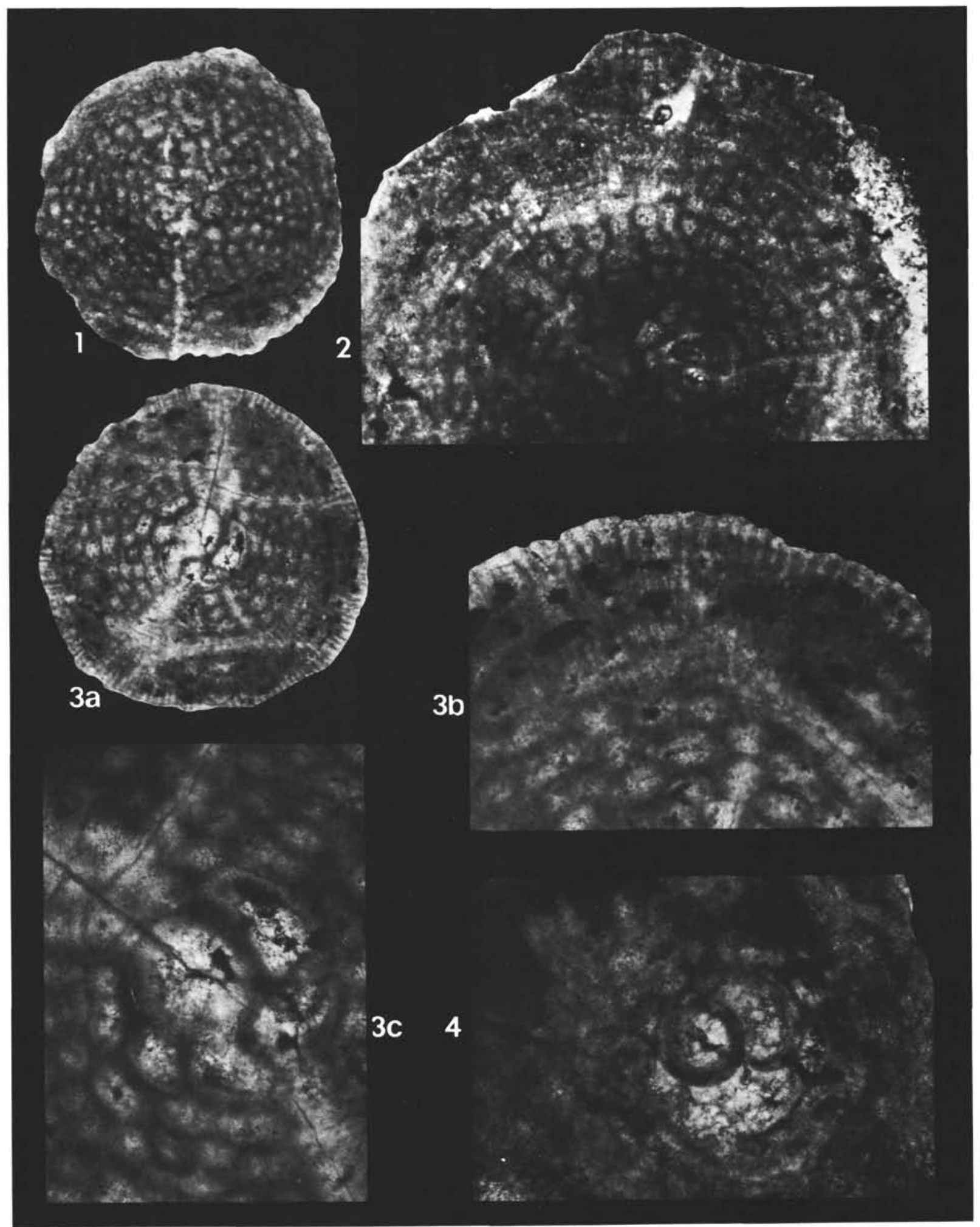

Plate 4. Photomicrographs.

Figure 1. Pseudorbitoides sp. Leg 61, Site 462, Core 51-3, 44-47 cm, late Campanian. Equatorial section, not centered, $\times 55.5$.

Figure 2. Vaughanina sp. Leg 61 , Site 462 , Core $52-1,101-107 \mathrm{~cm}$, late Campanian. Detail of marginal portion, same specimen as at Plate 5, Fig. 1, $\times 110$.
Figure 3. Pseudorbitoides israelskyi Vaughan and Cole. Leg 61. Site 462 , Core $52-1,98-101 \mathrm{~cm}$, late Campanian. A. Equatorial section, $\times 65$. B. Detail of the marginal portion, $\times 170$. C. Detail of nepionic stage, $\times 130$.

Figure 4. Orbitocyclina sp. Leg 61 , Site 462 , Core 48 soup, middle Maestrichtian. Detail of nepionic stage, same specimen as at Plate 9, Fig. 3, $\times 110$. 


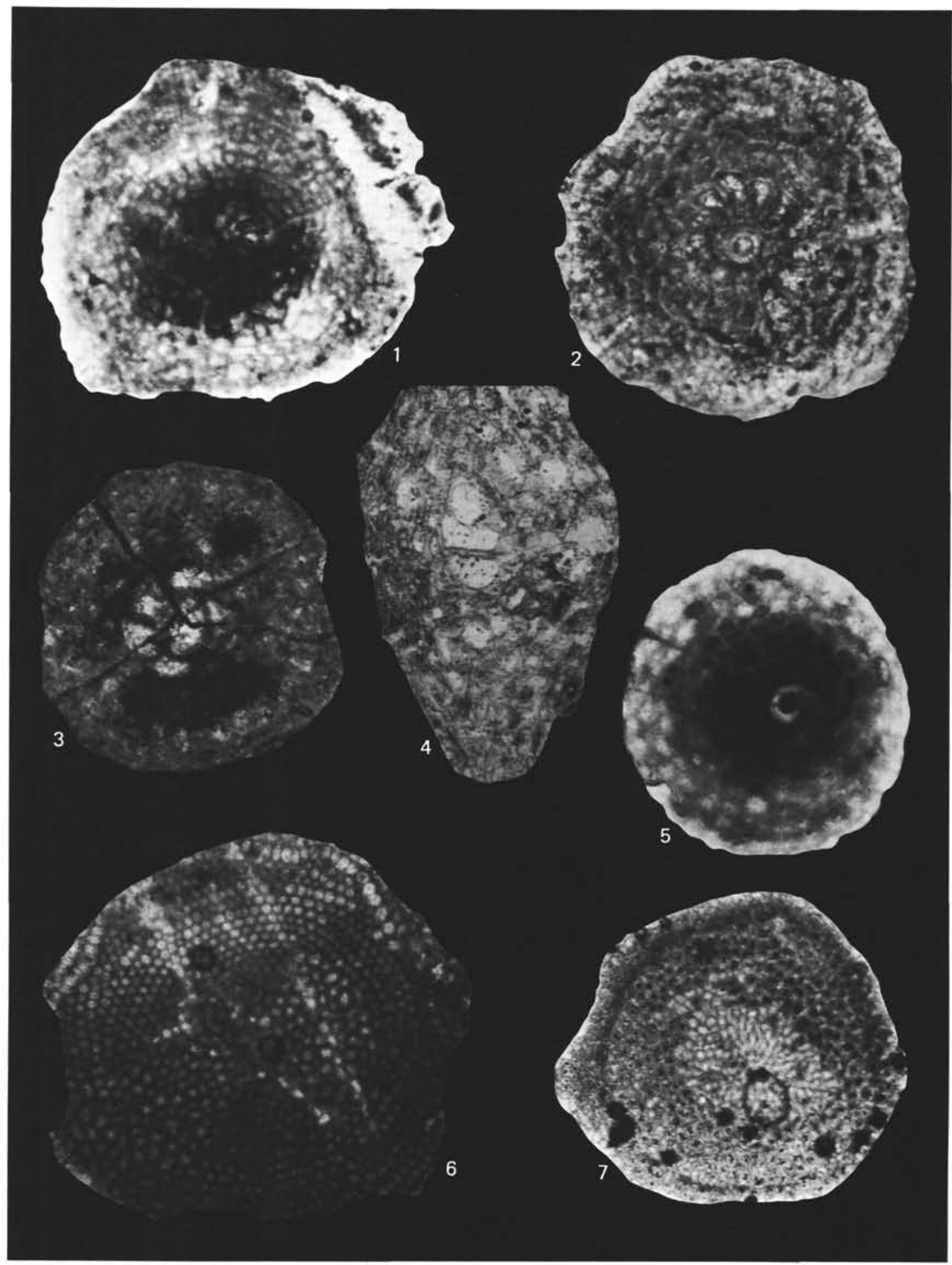

Plate 5. Photomicrographs.

Figure 1. Vaughanina sp. Leg 61, Site 462, Core 52-1, 101-107, late Campanian. Equatorial section, not centered, $\times 70$.

Figure 2. Vaughanina cubensis Palmer. Leg 61, Site 462, Core 52-1, 98-101 cm, late Campanian. Equatorial section, $\times 60$.

Figure 3. Pseudorbitoides sp. aff. $P$. israelskyi Vaughan and Cole. Leg 61 , Site 462 , Core 51-3, 44-47 cm, late Campanian. Equatorial section of poorly preserved specimen, $\times 60$.
Figure 4. Pseudorbitoides sp. aff. P. israelskyi Vaughan and Cole. Leg 61, Site 462, Core 21-1, 2-3 cm, late Oligocene. Axial section, $\times 120$.

Figure 5. Pseudorbitoides israelskyi Vaughan and Cole. Leg 61, Site 462, Core 52-1, 98-101 cm, late Campanian. Equatorial section, $\times 50$.

Figure 6. Lepidorbitoides socialis (Leymerie). Leg 61, Site 462, Core 48 soup, middle Maestrichtian. Equatorial section, not centered, $\times 80$.

Figure 7. Lepidorbitoides socialis (Leymerie). Leg 61. Site 462, Core 48 soup, middle Maestrichtian. Equatorial section, not centered, $\times 60$. 


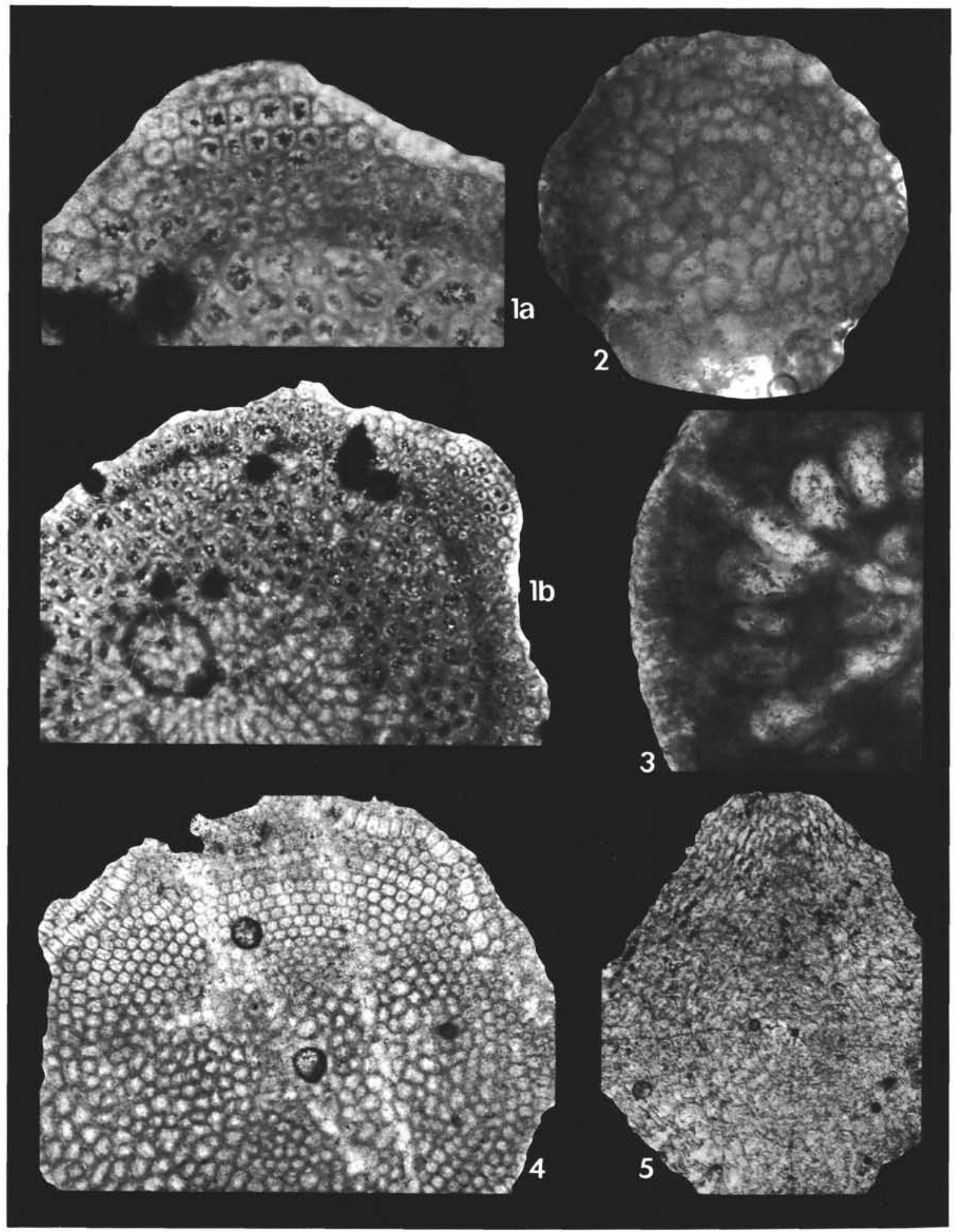

Plate 6. Photomicrographs.

Figure 1. Lepidorbitoides socialis (Leymerie). Leg 61, Site 462, Core 48 soup, middle Maestrichtian: Details of the marginal portion, same specimen as at Plate 5, Fig. 7. A. $\times 190$. B. $\times 92$.

Figure 2. Lepidorbitoides minor (Schlumberger). Leg 61, Site 462, Core 48 soup, middle Maestrichtian. Equatorial section passing through lateral chambers, $\times 74$.
Figure 3. Sulcoperculina cubensis Palmer. Leg 61, Site 462, Core 48$2,78-81 \mathrm{~cm}$, middle Maestrichtian. Part of equatorial section, $\times 92$.

Figure 4. Lepidorbitoides socialis (Leymerie). Leg 61, Site 462, Core 48 soup, middle Maestrichtian. Equatorial section, not centered, $\times 92$.

Figure 5. Asterorbis havanensis Palmer. Leg 61, Site 462, Core 48 soup, middle Maestrichtian. Equatorial section, not centered, $\times 65$. 


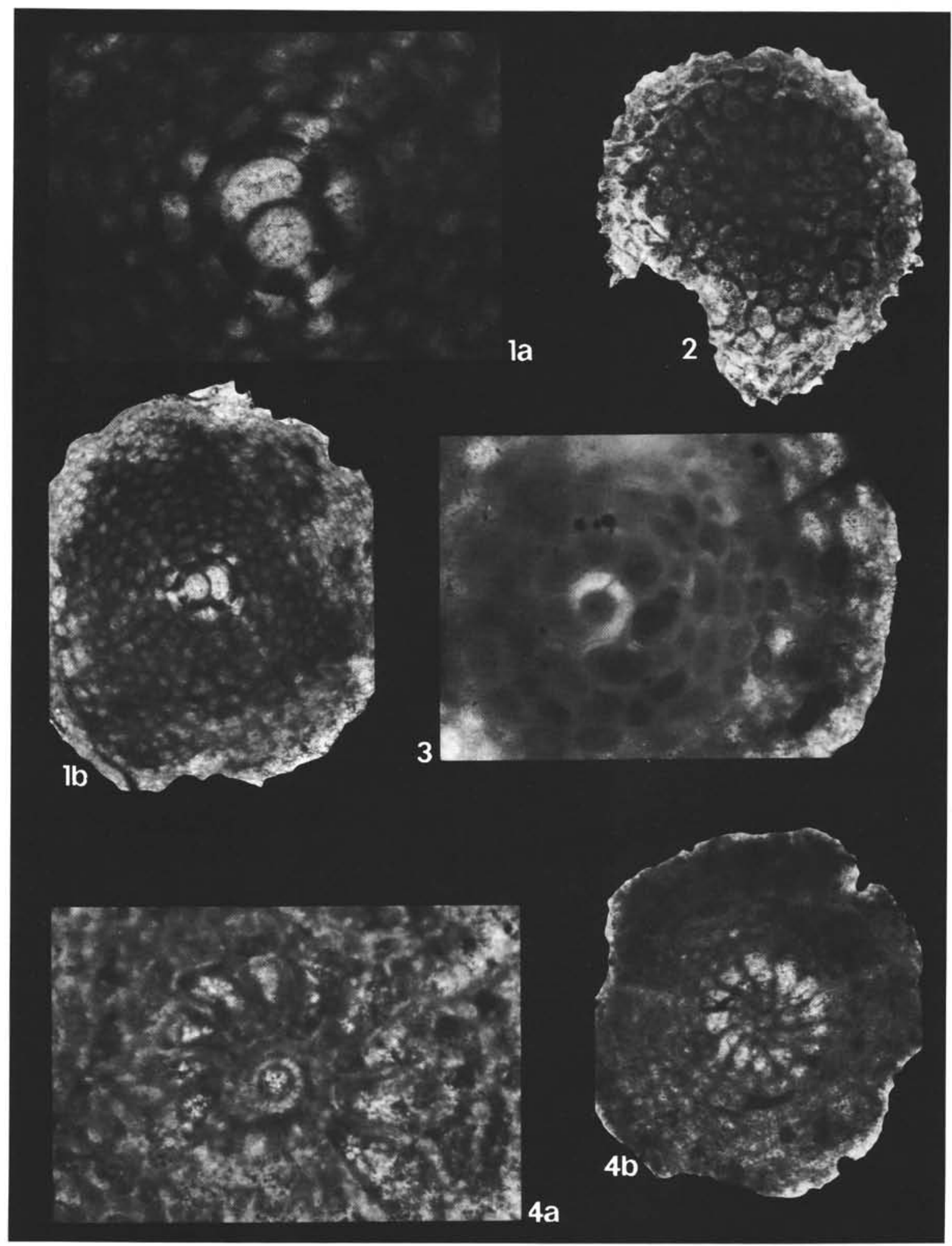

Plate 7. Photomicrographs.

Figure 1. Lepidorbitoides bisambergensis (Jaeger). Leg 61, Site 462, Core 48 soup, middle Maestrichtian. A. Nepionic stage of specimen figured in $\mathrm{B}, \times 155$. B. Equatorial section, $\times 65$.

Figure 2. Vaughanina sp. Leg 61 , Site 462 , Core $48, C C$, middle Maestrichtian. Tangent section through lateral chambers, $\times 55$.
Figure 3. Pseudorbitoides israelskyi Vaughan and Cole. Leg 61, Site 462, Core 52-1, 98-101 cm, late Campanian. Oblique equatorial section, $\times 92$.

Figure 4. Vaughanina cubensis Palmer. Leg 61, Site 462, Core 52-1, 98-101 cm, late Campanian. A. Nepionic spira of specimen in B, $\times 110$. B. Equatorial section, $\times 55$. 


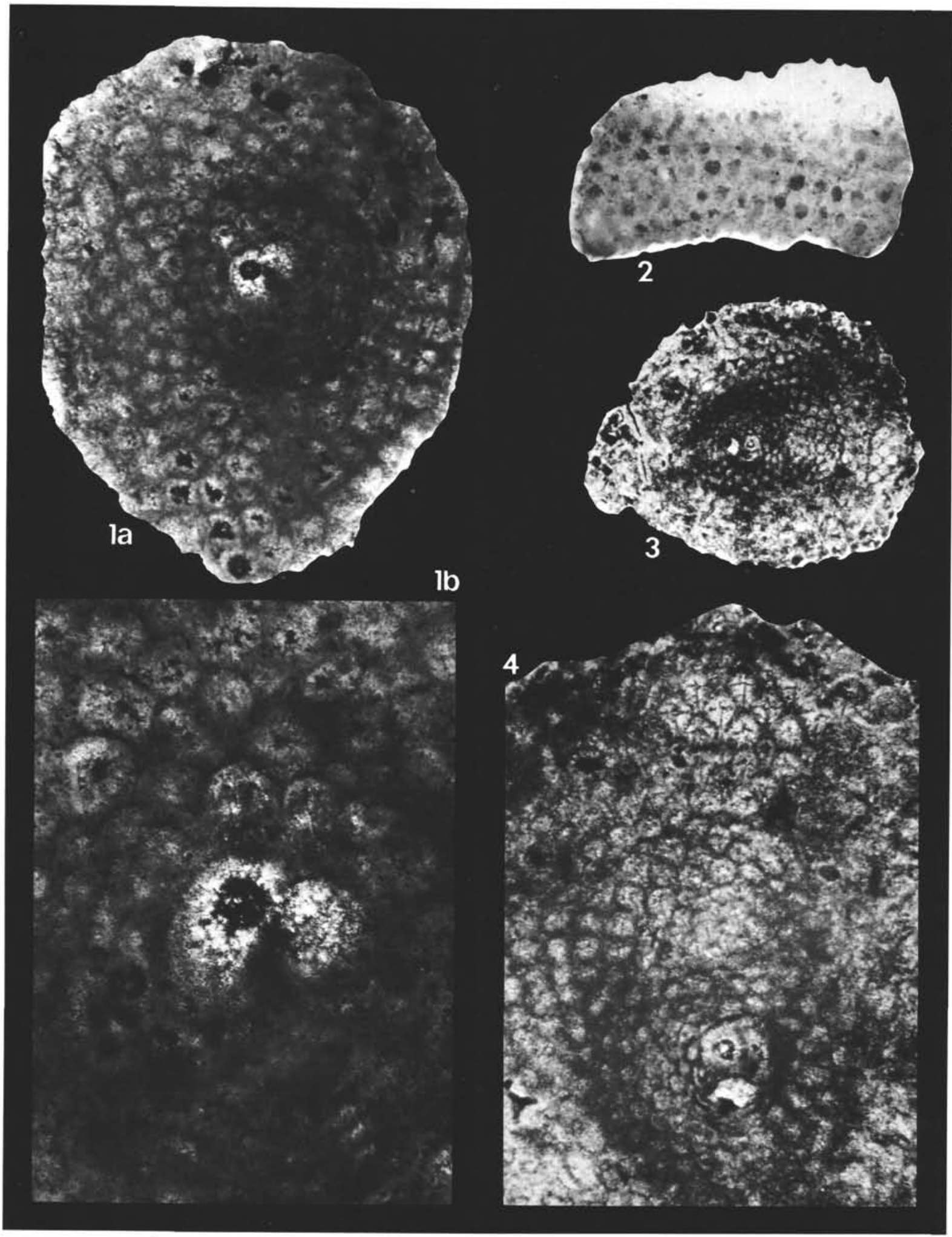

Plate 8. Photomicrographs.

Figure 1. Helicolepidina sp. aff. H. paucispira Barker and Grimsdale. Leg 61 , Site 462 , Core $32-1,5-8 \mathrm{~cm}$, early Oligocene. A. Slightly oblique equatorial section, $\times 83$. B. Detail of nepionic stage, $\times 200$.
Figure 2. Lepidocyclina (Eulepidina) sp. cf. L. ephippioides Jones and Chapman. Leg 61, Site 462, Core 22-1, 69-71 cm, late Oligocene. Section of the marginal portion (fragment), $\times 18.5$.

Figures 3, 4. Lepidorbitoides minor (Schlumberger). Leg 61, Site 462; Core 48,CC, middle Maestrichtian. 3. Equatorial section of poorly preserved specimen, $\times 28$. 4. Detail of $3, \times 80$. 


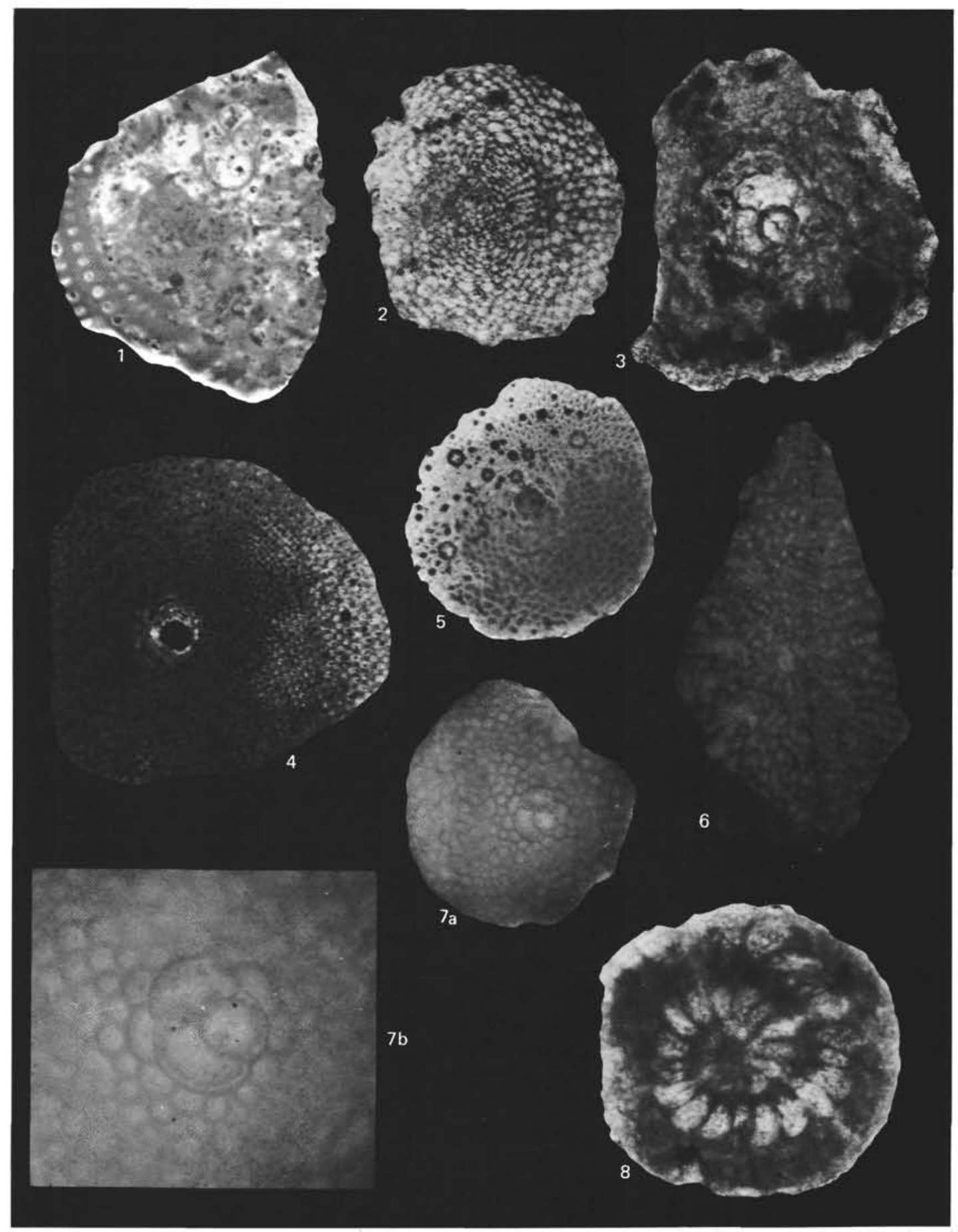

Plate 9. Photomicrographs.

Figure 1. Fasciolites? Leg 61 . Site 462 , Core $22-1,69-71 \mathrm{~cm}$, late Oligocene. Axial section with inside part destroyed and filled by extraneous material, same specimen as at Plate 17, Fig. 11 and Plate 14 , Fig. $6, \times 55$.

Figure 2. Polylepidina antillea (Cushman). Leg 61, Site 462, Core 22 $1,69-71 \mathrm{~cm}$, late Oligocene. Equatorial section of form B, $\times 46$.

Figure 3. Orbitocyclina sp. Leg 61 , Site 462 , Core 48 soup, middle Maestrichtian. Equatorial section of poorly preserved specimen, $\times 46$.
Figure 4. Lepidocyclina (Nephrolepidina) sumatrensis Cole. Leg 61, Site 462 , Core $22-1,69-71 \mathrm{~cm}$, late Oligocene. Slightly oblique equatorial section, $\times 23$.

Figure 5. Lepidocyclina (Nephrolepidina) sumatrensis Cole. Leg 61, Site 462 , Core $22-1,69-71 \mathrm{~cm}$, late Oligocene. Slightly oblique equatorial section, $\times 23$.

Figure 6. Discocyclina sp. Leg 61 , Site 462 , Core $32-1,5-8 \mathrm{~cm}$, early Oligocene. Oblique axial section $\times 18.5$.

Figures 7. Lepidorbitoides bisambergensis (Jaeger). Leg 61, Site 462, Core 48 soup, middle Maestrichtian. A. Equatorial section, $\times 45$. B. Detail of the nepionic stage, $\times 115$.

Figure 8. Sulcoperculina cubensis Palmer. Leg 61, Site 462, Core 48$2,78-81 \mathrm{~cm}$, middle Maestrichtian. Equatorial section, $\times 46$. 


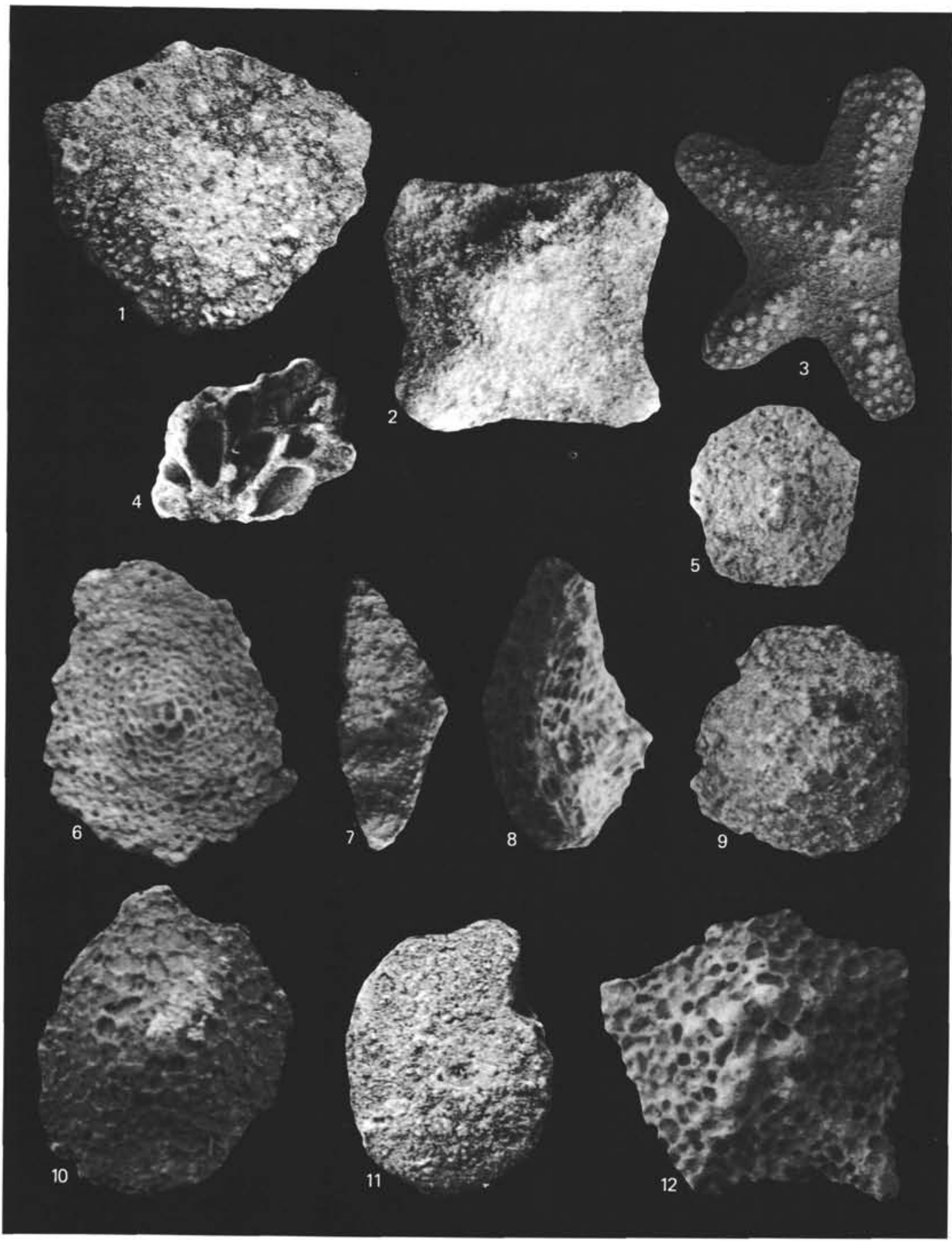

Plate 10. Photomicrographs.

Figure 1. Miogypsinoides grandipustula Cole. Leg 61, Site 462, Core $32-1,5-10 \mathrm{~cm}$, early Oligocene. External view, $\times 56$.

Figure 2. Asterocyclina matanzensis Cole. Leg 61, Site 462, Core 32 $1,73-75 \mathrm{~cm}$, early Oligocene. External view, $\times 47$.

Figure 3. Asterocyclina penuria Cole. Leg 61, Site 462, Core 22-1, $69-71 \mathrm{~cm}$, late Oligocene. External view, $\times 24$.

Figure 4. Miogypsinoides ubaghsi Tan Sin Hok, Leg 61, Site 462, Core $32-1,5-10 \mathrm{~cm}$, early Oligocene. Fragment of the equatorial layer, $\times 37$.

Figure 5. Pseudorbitoides sp. Leg 61, Site 462, Core 48 soup, middle Maestrichtian. External view, $\times 28$.
Figure 6. Orbitocyclina minima (Douvillé). Leg 61, Site 462. Core 48$2,78-81 \mathrm{~cm}$, middle Maestrichtian. Equatorial layer, $\times 28$.

Figure 7. Orbitocyclina sp. Leg 61 , Site 462 , Core $48-2,78-81 \mathrm{~cm}$, middle Maestrichtian. Axial section of broken specimen, $\times 47$.

Figure 8. Pseudorbitoides sp. Leg 61, Site 462, Core 52-1, 98-101 cm, late Campanian. Broken specimen along about the axial section, $\times 58$.

Figure 9. Vaughanina cubensis Palmer. Leg 61, Site 462, Core 51-3, 44-47 cm, late Campanian. External view, $\times 37$.

Figure 10. Vaughanian sp. Leg 61 , Site 462 , Core $52-1,98-101 \mathrm{~cm}$, late Campanian. External view, $\times 47$.

Figure 11. Rotalia sp. Leg 61, Site 462, Core 32-1, 5-8 cm, early Oligocene. Spiral view, $\times 37$.

Figure 12. Asterorbis cubensis Palmer. Leg 61, Site 462, Core 48-2, $78-81 \mathrm{~cm}$, middle Maestrichtian. External view, $\times 56$. 


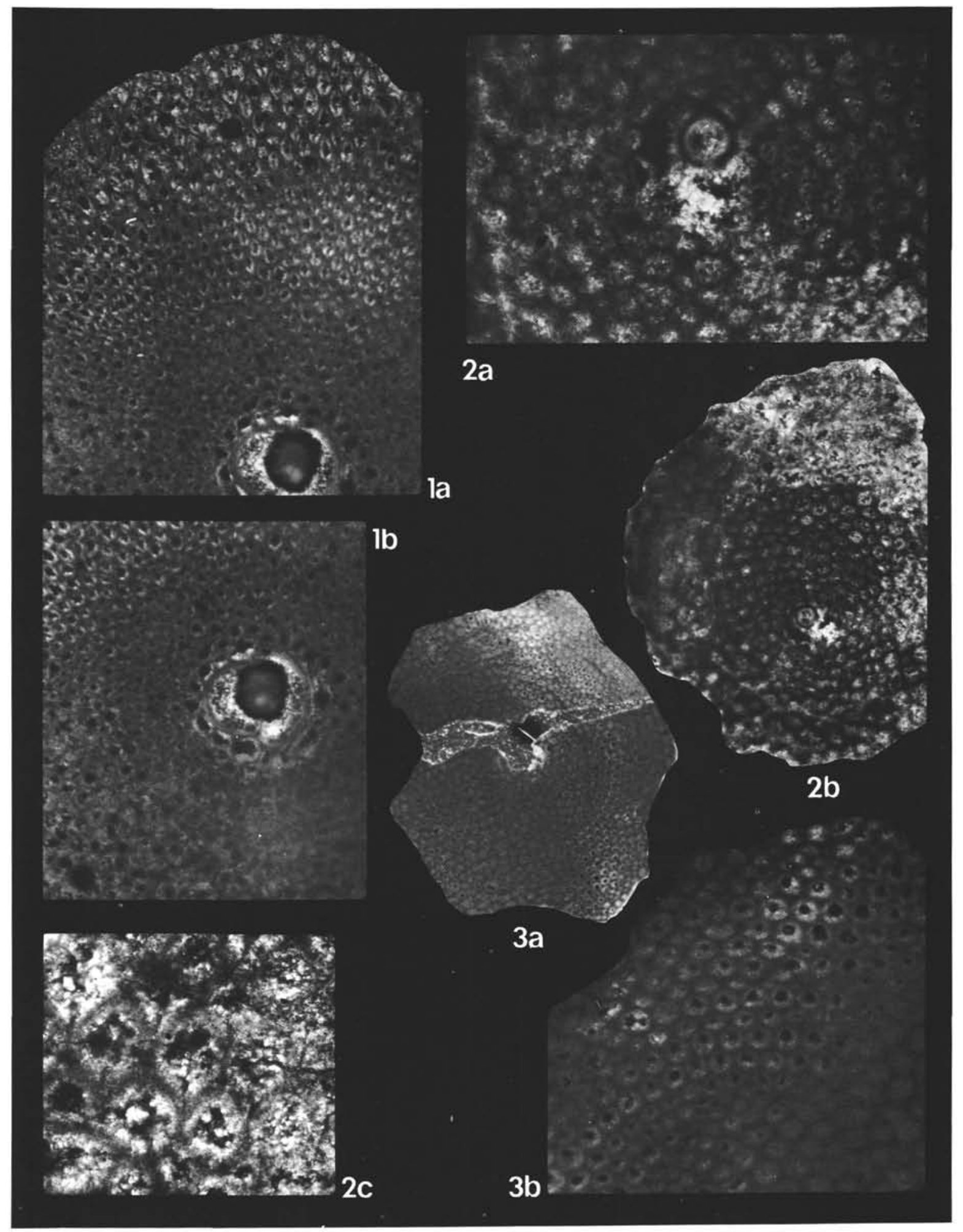

Plate 11. Photomicrographs.

Figure 1. Lepidocyclina (Nephrolepidina) sumatrensis Cole. Leg 61, Site 462 , Core $22-1,69-71 \mathrm{~cm}$, late Oligocene. A. Portion of equatorial section, $\times 46$. B. Equatorial section of nepionic stage, $\times 46$.
Figure 2. Lepidorbitoides minor (Schlumberger). Leg 61, Site 462, Core 48,CC, middle Maestrichtian. A. Detail of the embrionic portion, $\times 115$. B. Equatorial section, $\times 46$. C. Detail of the marginal portion, $\times 135$.

Figure 3. Lepidocyclina sp. Leg 61 , Site 462 , Core $22-1,69-71 \mathrm{~cm}$, late Oligocene. A. Slightly oblique equatorial section, $\times 55$. B. Detail of $A, \times 145$. 


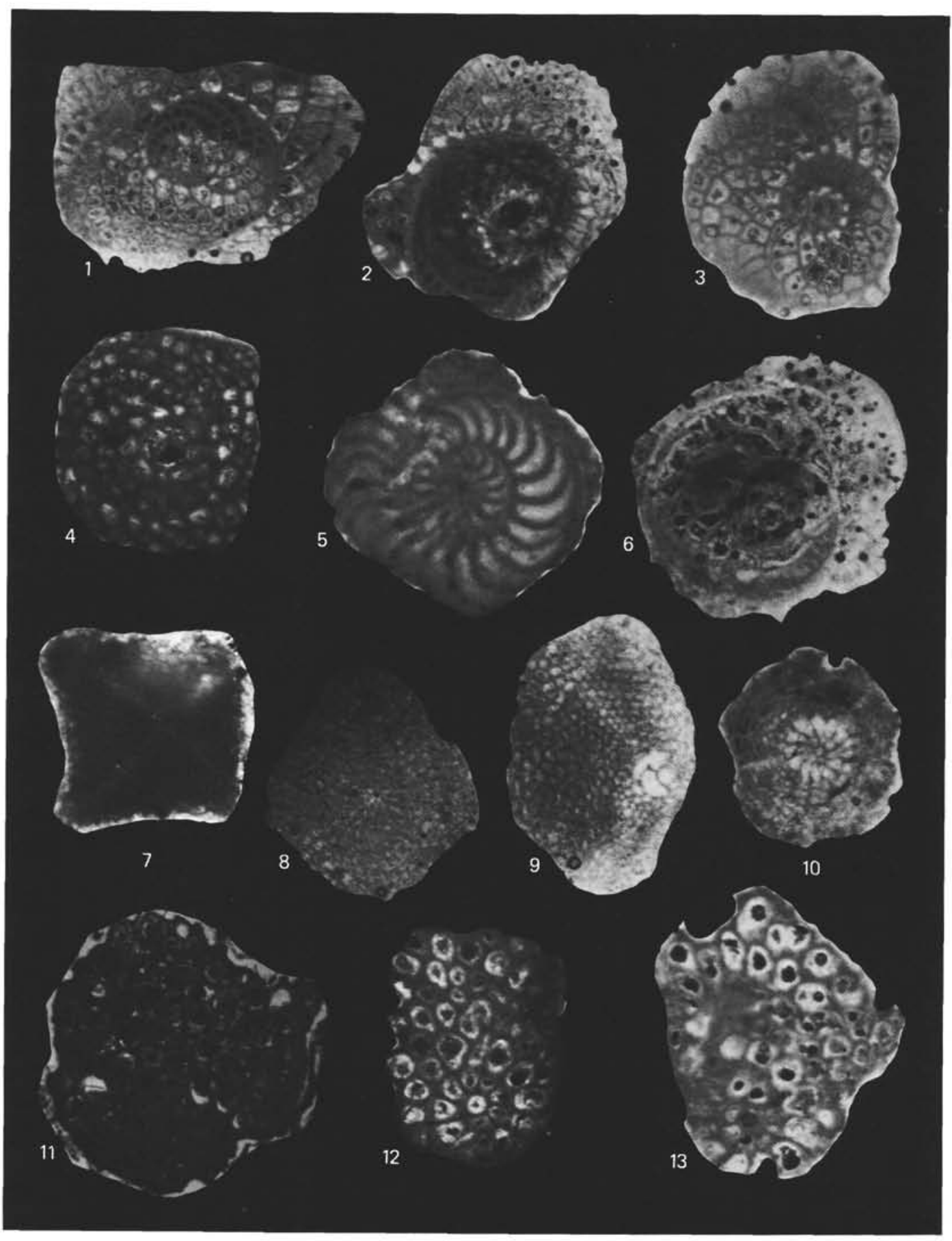

Plate 12. Photomicrographs.

Figure 1. Spiroclypeus sp. cf. S. vermicularis Tan. Leg 61, Site 462, Core 22-1, 69-71 cm, late Oligocene. Equatorial section, $\times 20$.

Figure 2. Spiroclypeus sp. cf. S. vermicularis Tan. Leg 61, Site 462, Core $32-1,5-10 \mathrm{~cm}$, early Oligocene. Oblique equatorial section, $\times 25$.

Figure 3. Heterostegina saipanensis Cole. Leg 61, Site 462, Core $22-1,69-71 \mathrm{~cm}$, late Oligocene. Equatorial section, $\times 20$.

Figure 4. Spiroclypeus higginsi Cole. Leg 61, Site 462, Core 32-1, 5-8 $\mathrm{cm}$, early Oligocene. Equatorial section, $\times 50$.

Figure 5. Operculina subformai (Provale). Leg 61, Site 462, Core 32 $1,5-8 \mathrm{~cm}$, early Oligocene. Equatorial section, not centered, $\times 50$.

Figure 6. Heterostegina suborbicularis (d'Orbigny). Leg 61, Site 462, Core 22-1, 69-71 cm, early Oligocene. Equatorial section, $\times 50$.
Figure 7. Asterocyclina matanzensis Cole. Leg 61, Site 462, Core 32 $1,73-75 \mathrm{~cm}$, early Oligocene. Equatorial section, not centered, $\times 40$.

Figure 8. Asterorbis havanesis Palmer. Leg 61, Site 462, Core 48 soup, middle Maestrichtian. Equatorial section, not centered, $\times 40$.

Figure 9. Polylepidina sp. Leg 61, Site 462, Core 34,CC, late Eocene. Oblique section, $\times 25$.

Figure 10. Vaughanina cubensis Palmer. Leg 61, Site 462, Core 52-1, 98-101 cm, late Campanian. Equatorial section, not centered, $\times 30$.

Figure 11. Miogypsinoides ubaghsi Tan. Leg 61, Site 462, Core 32-1, 5-10 cm, early Oligocene. Equatorial section, $\times 50$.

Figure 12. Miogypsinoides ubaghsi Tan. Leg 61, Site 462, Core 32-1, $5-10 \mathrm{~cm}$, early Oligocene. Equatorial section, $\times 50$.

Figure 13. Miogypsinoides ubaghsi Tan. Leg 61, Site 462, Core $34, \mathrm{CC}$, late Eocene. Equatorial section, $\times 50$. 


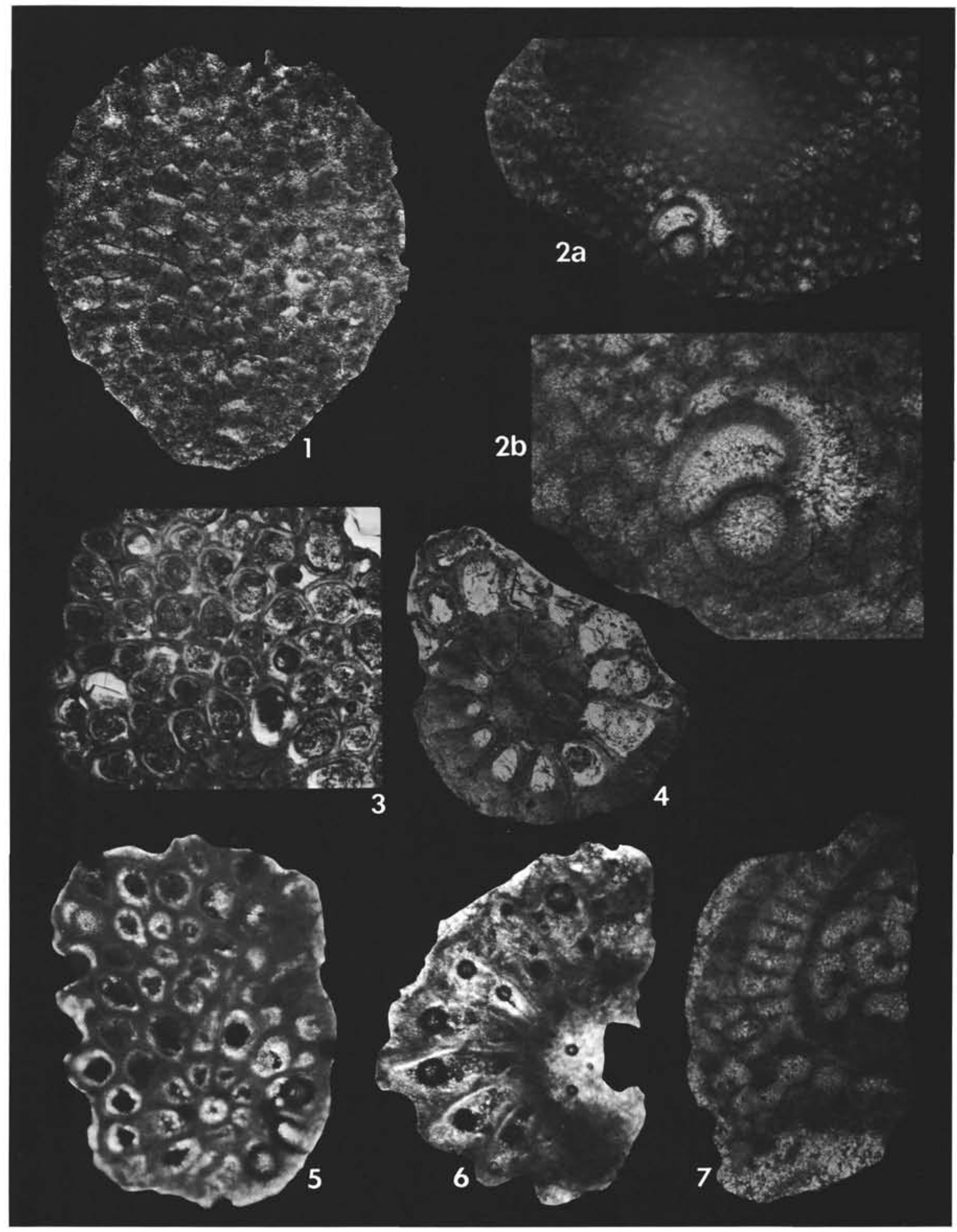

Plate 13. Photomicrographs.

Figure 1. Miogypsinoides ubaghsi Tan. Leg 61, Site 462, Core 32-1, 5-10 cm, early Oligocene. Tangent section, $\times 70$.

Figure 2. Polylepidina sp. Leg 61, Site 462, Core 34,CC, late Eocene. A. Oblique equatorial section, $\times 88$. B. Detail of $\mathrm{A}, \times 210$.

Figure 3. Miogypsinoides ubaghsi Tan. Leg 61, Site 462, Core 32-1, 5-10 cm, early Oligocene. Equatorial section, marginal portion, $\times 60$.
Figure 4. Miogypsinoides grandipustula Cole. Leg 61, Site 462, Core $32-1,5-10 \mathrm{~cm}$, early Oligocene. Equatorial section, not centered, $\times 55$.

Figure 5. Miogypsinoides ubaghsi Tan. Leg 61, Site 462, Core 32-1, 5-10 cm, early Oligocene. Equatorial section, $\times 53$.

Figure 6. Miogypsinoides grandipustula Cole. Leg 61. Site 462, Core $32-1,5-10 \mathrm{~cm}$, early Oligocene. Oblique section, $\times 55$.

Figure 7. Dictyoconus sp. aff. D. saipanensis Cole. Leg 61, Site 462, Core $21-1,2-3 \mathrm{~cm}$, late Oligocene. Oblique section, $\times 50$. 


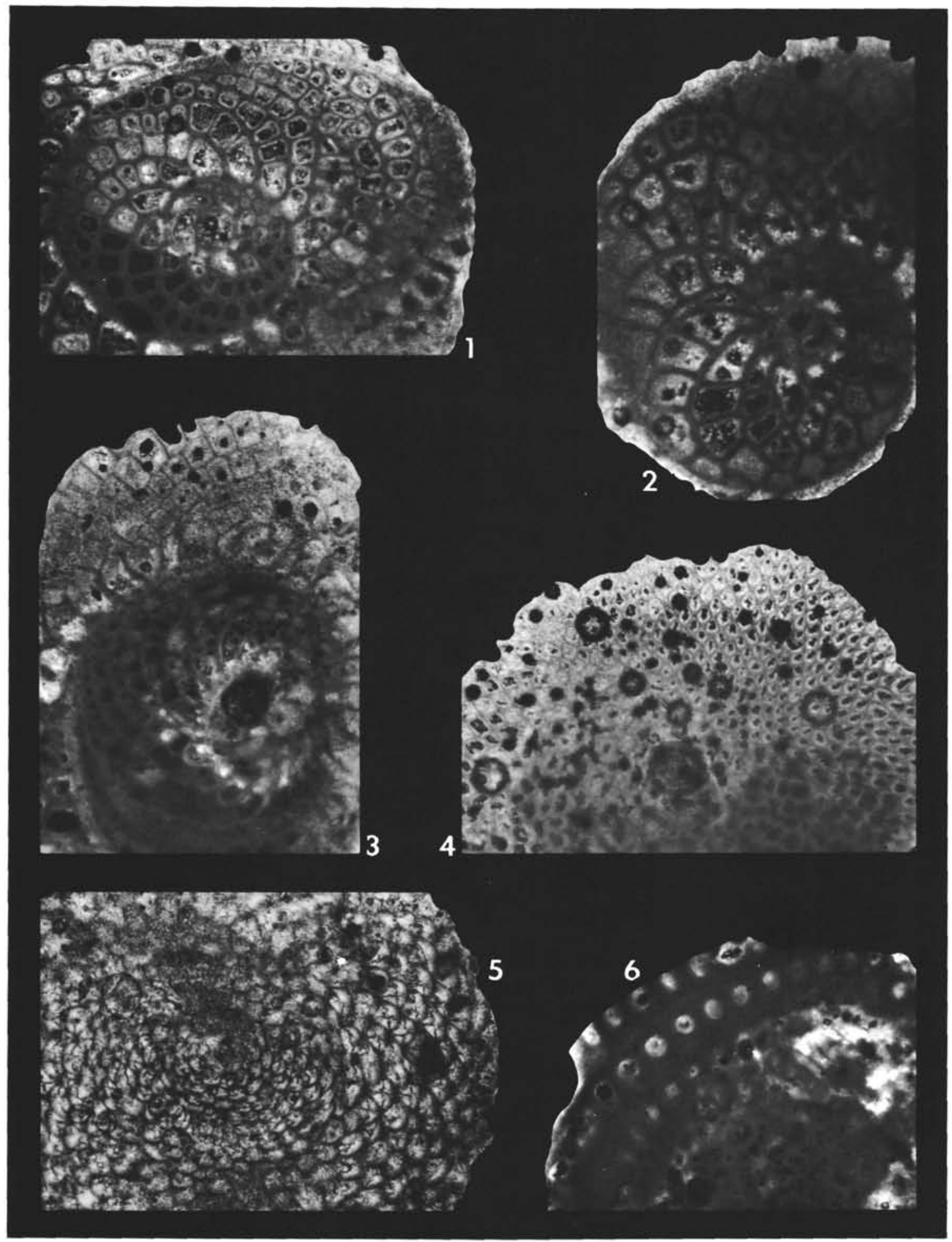

Plate 14. Photomicrographs.

Figure 1. Heterostegina saipanensis Cole. Leg 61, Site 462, Core 22 $1,69-71 \mathrm{~cm}$, late Oligocene. Slightly oblique equatorial section, $\times 46$.

Figure 2. Spiroclypeus cf. vermicularis Tan. Leg 61, Site 462, Core 22-1, 69-71 cm, late Oligocene. Equatorial section, $\times 27.5$

Figure 3. Spiroclypeus sp. cf. S. vermicularis Tan. Leg 61, Site 462, Core $22-1,69-71 \mathrm{~cm}$, late Oligocene. Equatorial section, $\times 46$.
Figure 4. Lepidocyclina (Nephrolepidina) sumatrensis (Brady) Leg 61 , Site 462 , Core $22-1,69-71 \mathrm{~cm}$, late Oligocene. Slightly oblique equatorial section, $\times 46$.

Figure 5. Polylepidina antillea (Cushman). Leg 61, Site 462, Core $22-1,69-71 \mathrm{~cm}$, late Oligocene. Equatorial section of form B, $\times 92$.

Figure 6. Fasciolites? Leg 61, Site 462, Core 22-1, 69-71 cm, late Oligocene. Detail of Plate 9, Fig. 1, same specimen as in Plate 17, Fig. $11, \times 110$. 


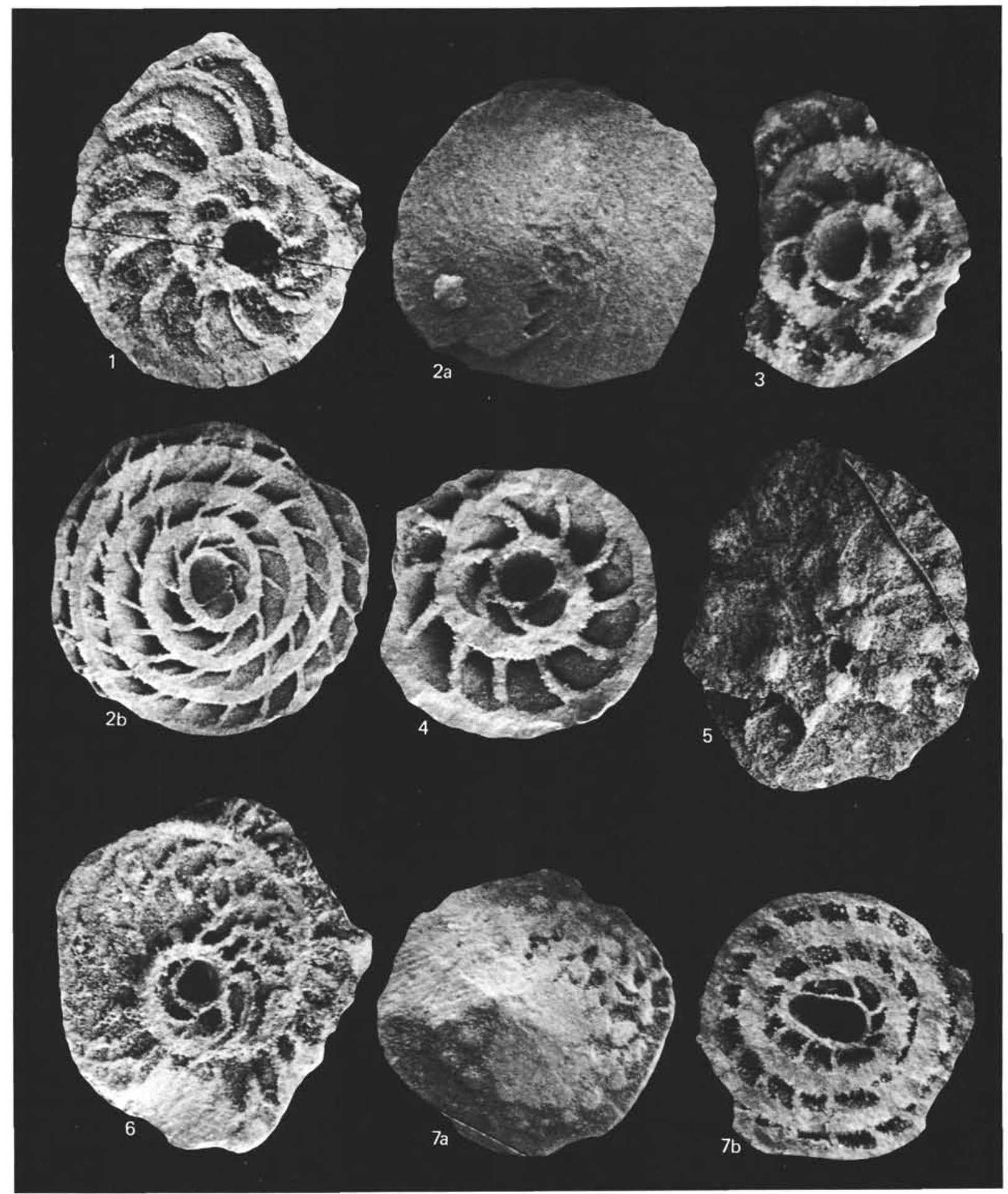

Plate 15. Photomicrographs.

Figure 1. Operculina eniwetokensis Cole. Leg 61, Site 462, Core 32$1,5-8 \mathrm{~cm}$, early Oligocene. Spiral view, $\times 65$.

Figure 2. Nummulites rotularius Deshayes. Leg 61, Site 462, Core $22-1,69-71 \mathrm{~cm}$, late Oligocene. A. External view, $\times 55$. B. Spiral view, $\times 55$.

Figure 3. Nummulites sp. Leg 61, Site 462 , Core $32-1,5-8 \mathrm{~cm}$, early Oligocene. Spiral view, $\times 28$.
Figure 4. Nummulites sp. Leg 61 , Site 462 , Core $32-1,5-8 \mathrm{~cm}$, early Oligocene. Spiral view, $\times 46$.

Figure 5. Nummulites burdigalensis minor (de la Harpe). Leg 61, Site 462 , Core $32-1,5-8 \mathrm{~cm}$, early Oligocene. External view, $\times 46$.

Figure 6. Heterostegina sp. Leg 61 , Site 462 , Core $32-1,5-8 \mathrm{~cm}$, early Oligocene. Spiral view, $\times 55$.

Figure 7. Nummulites problematicus (Tellini). Leg 61, Site 462, Core $32-1,5-8 \mathrm{~cm}$, early Oligocene. A. External view, $\times 55$. B. Spiral view, $\times 55$. 


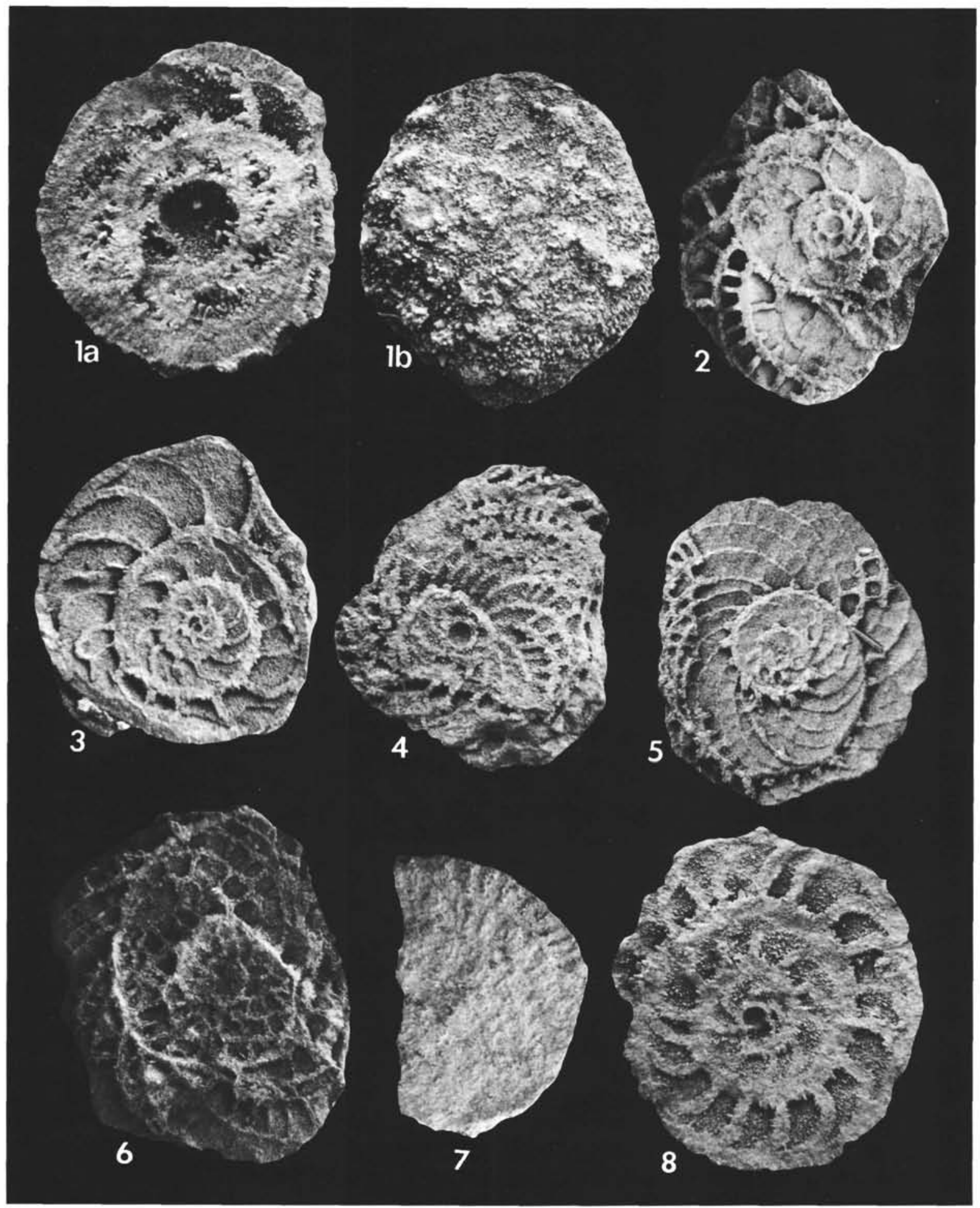

Plate 16. Photomicrographs.

Figure 1. Nummulites partschi (de la Harpe). Leg 61, Site 462, Core 21-1, 2-3 cm, late Oligocene. A. Spiral view, $\times 55$. B. External view, $\times 55$.

Figure 2. Heterostegina borneensis Van der Vlerk. Leg 61, Site 462, Core 22-1, 69-71 cm, late Oligocene. Spiral view, $\times 46$.

Figure 3. Heterostegina suborbicularis (d'Orbigny). Leg 61, Site 462, Core $22-1,69-71 \mathrm{~cm}$, late Oligocene. Spiral view, $\times 46$.
Figure 4. Heterostegina sp. aff. H. borneensis. Leg 61, Site 462, Core $22-1,69-71 \mathrm{~cm}$, late Oligocene. Spiral view, $\times 46$.

Figure 5. Heterostegina saipanensis Cole. Leg 61, Site 462, Core 22-1, $69-71 \mathrm{~cm}$, late Oligocene. Spiral view, $\times 23$.

Figure 6. Heterostegina borneensis Van der Vlerk. Leg 61, Site 462, Core 22-1, 69-71 cm, late Oligocene. Spiral view, $\times 55$.

Figure 7. Spiroclypeus? sp. Leg 61, Site 462, Core 34,CC, late Eocene. External view, $\times 28$.

Figure 8. Assilina leymerieri (d'Archiac and Haime). Leg 61, Site 462 , Core $22-1,69-71 \mathrm{~cm}$, late Oligocene. Spiral view, $\times 55$. 


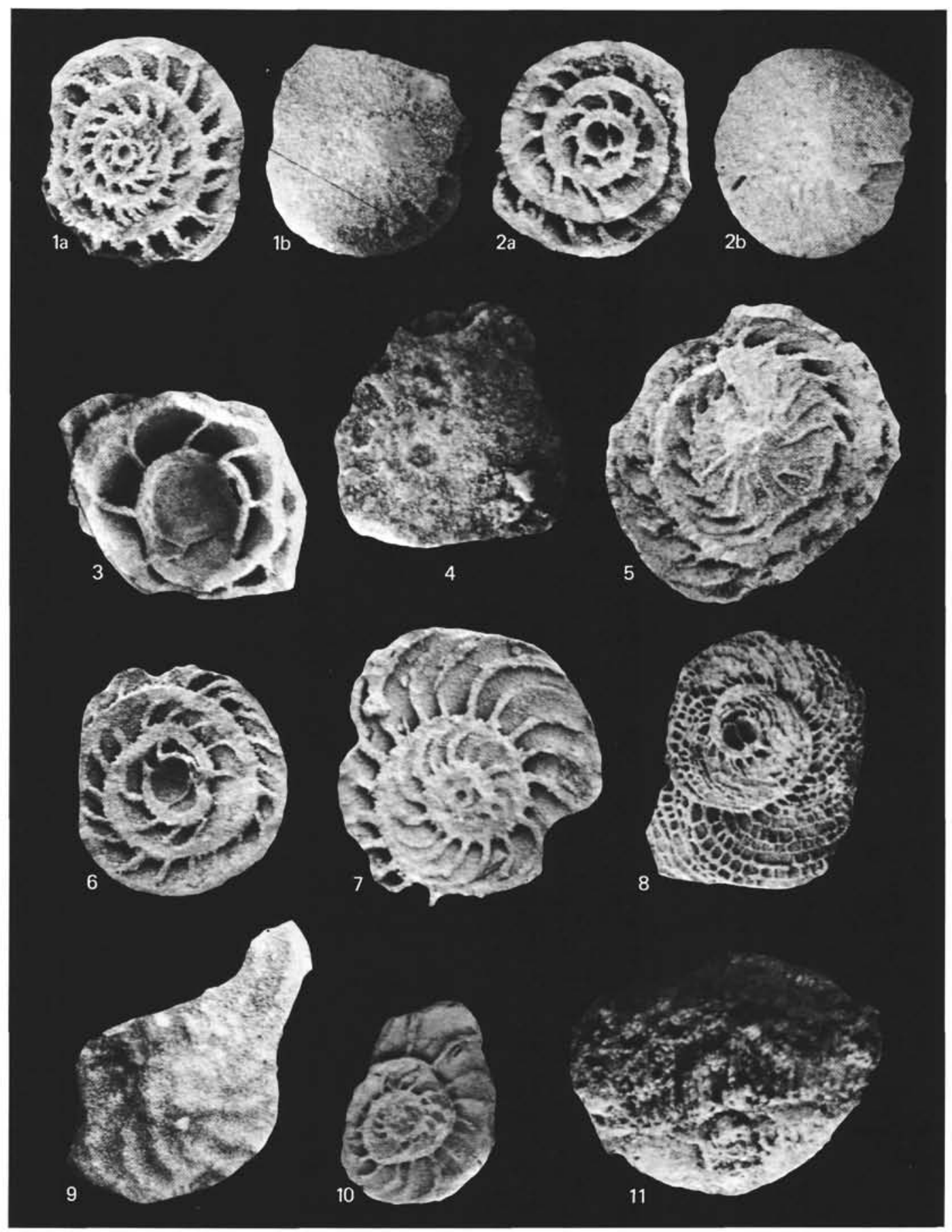

Plate 17. Photomicrographs.

Figure 1. Nummulites pernotus Schaub. Leg 61, Site 462, Core 22-1, $69-71 \mathrm{~cm}$, late Oligocene. A. Spiral view, $\times 40$. B. External view, $\times 40$.

Figure 2. Nummulites sp. aff. N. variolarius (Lamarck). Leg 61, Site 462 , Core $22-1,69-71 \mathrm{~cm}$, late Oligocene. A. Spiral view, $\times 40$. B. External view, $\times 40$.

Figure 3. Nummulites sp. cf. $N$. bagelensis (Veerbek). Leg 61, Site 462 , Core 22-1, 69-71 cm, late Oligocene. Spiral view, fragment, $\times 40$.

Figure 4. Assilina leymeriei (d'Archiac and Haime). Leg 61, Site 462, Core 22-1, 69-71 cm, late Oligocene. External view, $\times 25$.

Figure 5. Nummulites bouillei (de la Harpe). Leg 61, Site 462, Core $32-1,5-8 \mathrm{~cm}$, early Oligocene. Partially peeled specimen, $\times 50$.
Figure 6. Nummulites burdigalensis minor (de la Harpe). Leg 61, Site 462 , Core $32-1,5-8 \mathrm{~cm}$, early Oligocene. Spiral view, $\times 20$.

Figure 7. Operculina subformai (Provale). Leg 61, Site 462, Core $32-1,5-8 \mathrm{~cm}$, early Oligocene. Spiral view, $\times 50$.

Figure 8. Spiroclypeus sp. cf. vermicularis Tan. Leg 61 , Site 462, Core $32-1,5-8 \mathrm{~cm}$, early Oligocene. Spiral view, $\times 20$.

Figure 9. Operculina sp. cf. O. complanata (Defrance). Leg 61, Site 462, Core 22-1, 69-71 cm, late Oligocene. External view, $\times 15$.

Figure 10. Heterostegina suborbicularis (d'Orbigny). Leg 61, Site 462 , Core $32-1,5-8 \mathrm{~cm}$, early Oligocene. Spiral view, $\times 15$.

Figure 11. Fasciolites? Leg 61, Site 462, Core 22-1, 69-71 cm, late Oligocene. External view, same specimen as at Plate 9, Fig. 1, and Plate 14, Fig. 6, $\times 60$. 


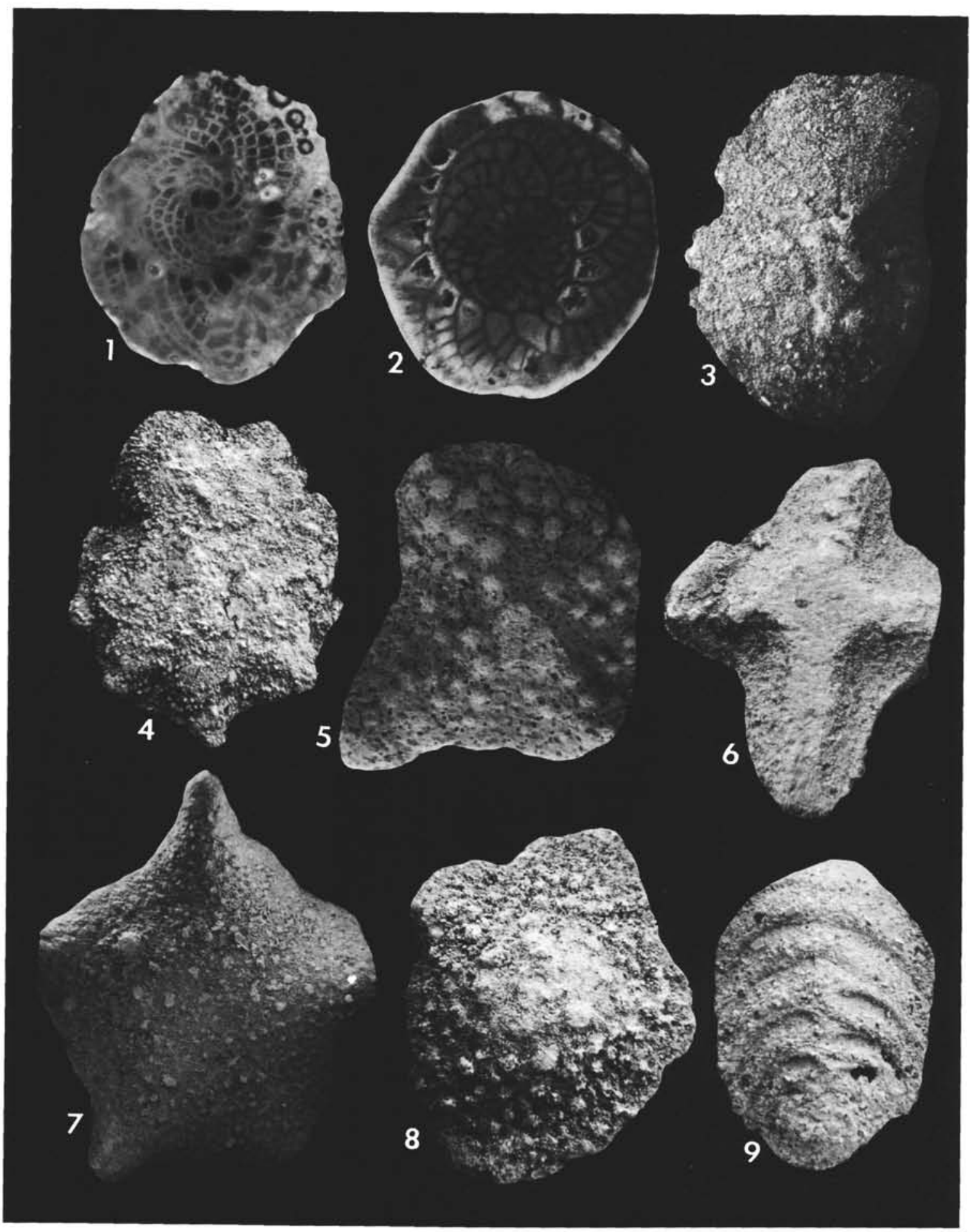

Plate 18. Photomicrographs.

Figure 1. Spiroclypeus sp. cf. S. vermicularis Tan. Leg 61, Site 462, Core 22-1, 69-71 cm, late Oligocene. Equatorial section, $\times 23$.

Figure 2. Spiroclypeus sp. cf. S. albapustula Cole. Leg 61, Site 462, Core 22-1, 69-71 cm, late Oligocene. Equatorial section, not centered, $\times 18.5$.

Figure 3. Rotalia sp. Leg 61 , Site 462 , Core $14-5,78-81 \mathrm{~cm}$, middle Miocene. Ventral view, $\times 18.5$.

Figure 4. Pararotalia sp. aff. P. byramensis (Cushman). Leg 61, Site 462 , Core $32-1,5-8 \mathrm{~cm}$, early Oligocene. Ventral view, $\times 18.5$.
Figure 5. Asterocyclina malladai Gomez Llueca. Leg 61, Site 462, Core 22-1, 69-71 cm, late Oligocene. External view, $\times 18.5$.

Figure 6. Asterocyclina matanzensis Cole. Leg 61, Site 462, Core $32-1,73-75 \mathrm{~cm}$, early Oligocene. External view, $\times 28$.

Figure 7. Asterocyclina malladai Gomez Llueca. Leg 61, Site 462, Core 22-1, 69-71 cm, late Oligocene. External view, $\times 28$.

Figure 8. Asterocyclina penuria Cole. Leg 61, Site 462, Core 22-1, 69$71 \mathrm{~cm}$, late Oligocene. External view, $\times 18.5$.

Figure 9. Vulvulina sp. Leg 61 , Site 462 , Core $32-1,5-8 \mathrm{~cm}$, early Oligocene, $\times 28$. 


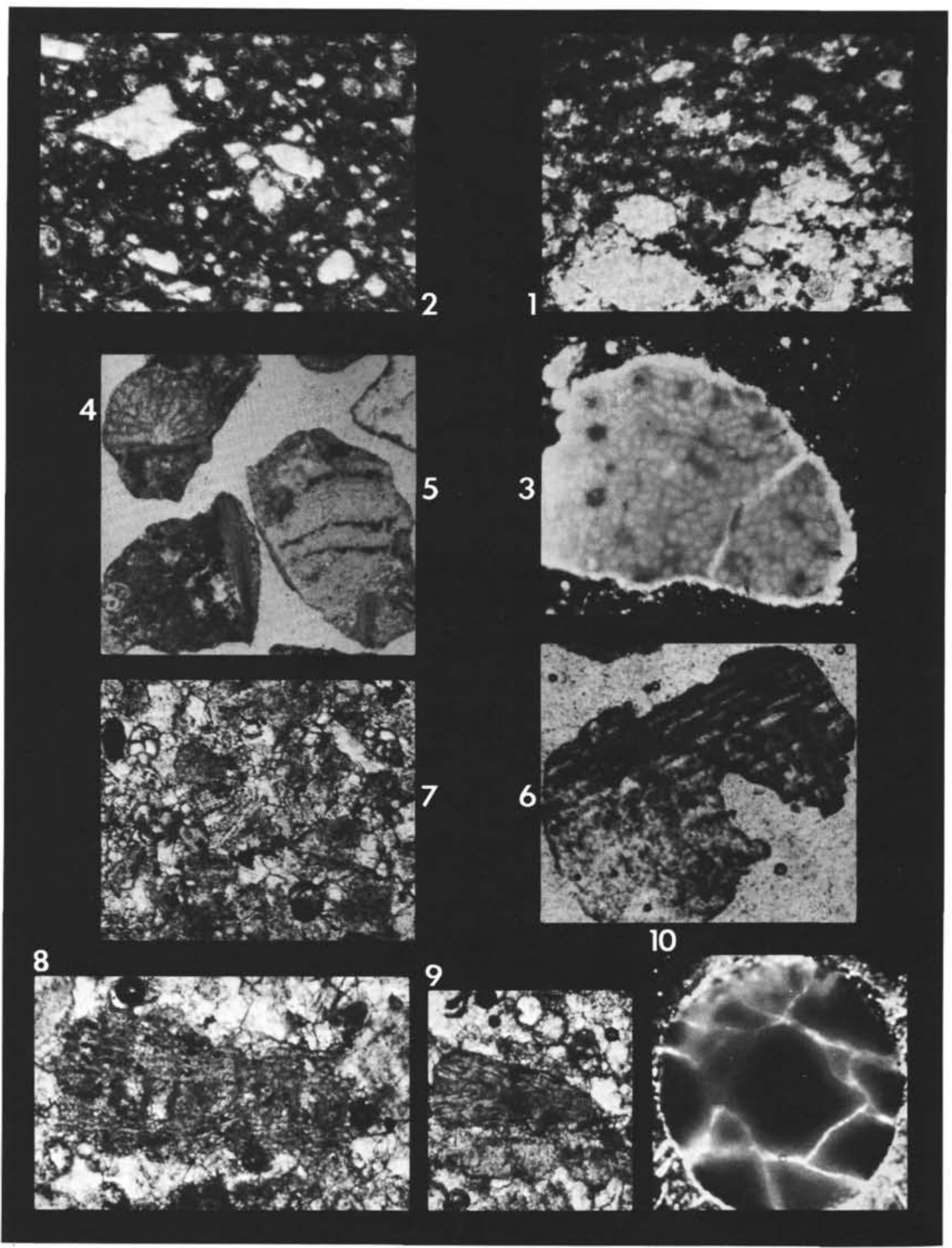

Plate 19. Photomicrographs.

Figures 1, 2. Leg 61, Site 462A, Core H2-1, 125-131 cm, late Oligocene. Thin sections. 1. Bottom. 2. Top of a coarser layer containing heavily recrystallized larger foraminifers (arrows), possibly discocyclinids, $\times 25$.

Figure 3. Discocyclina sp. Leg 61, Site 462, Core $14-5,79-81 \mathrm{~cm}$, early Miocene. Thin section tangent to surface, $\times 20$.

Figure 4. Sphaerogypsina sp. Leg 61, Site 462, Core 21-1, 2-3 cm, late Oligocene. Thin section, $\times 24$.

Figure 5. Fragment of rudistid. Leg 61, Site 462, Core 21-1, 2-3 cm, late Oligocene. Thin section, $\times 24$.
Figure 6. Fragment of rudistid. Leg 61 Site 462 , Core $22-1,69-71 \mathrm{~cm}$, late Oligocene. Thin section, $\times 24$.

Figure 7. Leg 61, Site 462, Core 48,CC, middle Maestrichtian. Thin section of coarse layer, $\times 30$.

Figure 8. Leg 17, Site 165A, Core 16,CC, middle(?) Maestrichtian. Fragment of Pseudorbitoides sp. Axial section, $\times 65$.

Figure 9. Leg 17, Site 165A, Core 16,CC, middle(?) Maestrichtian. Fragment of Vaughanina? sp. Axial section, $\times 65$.

Figure 10. Leg 61, Site 462, Core 22-1, 69-71 cm, late Oligocene. Equatorial section of badly preserved specimen of orbitoidal foraminifer, $\times 50$. 


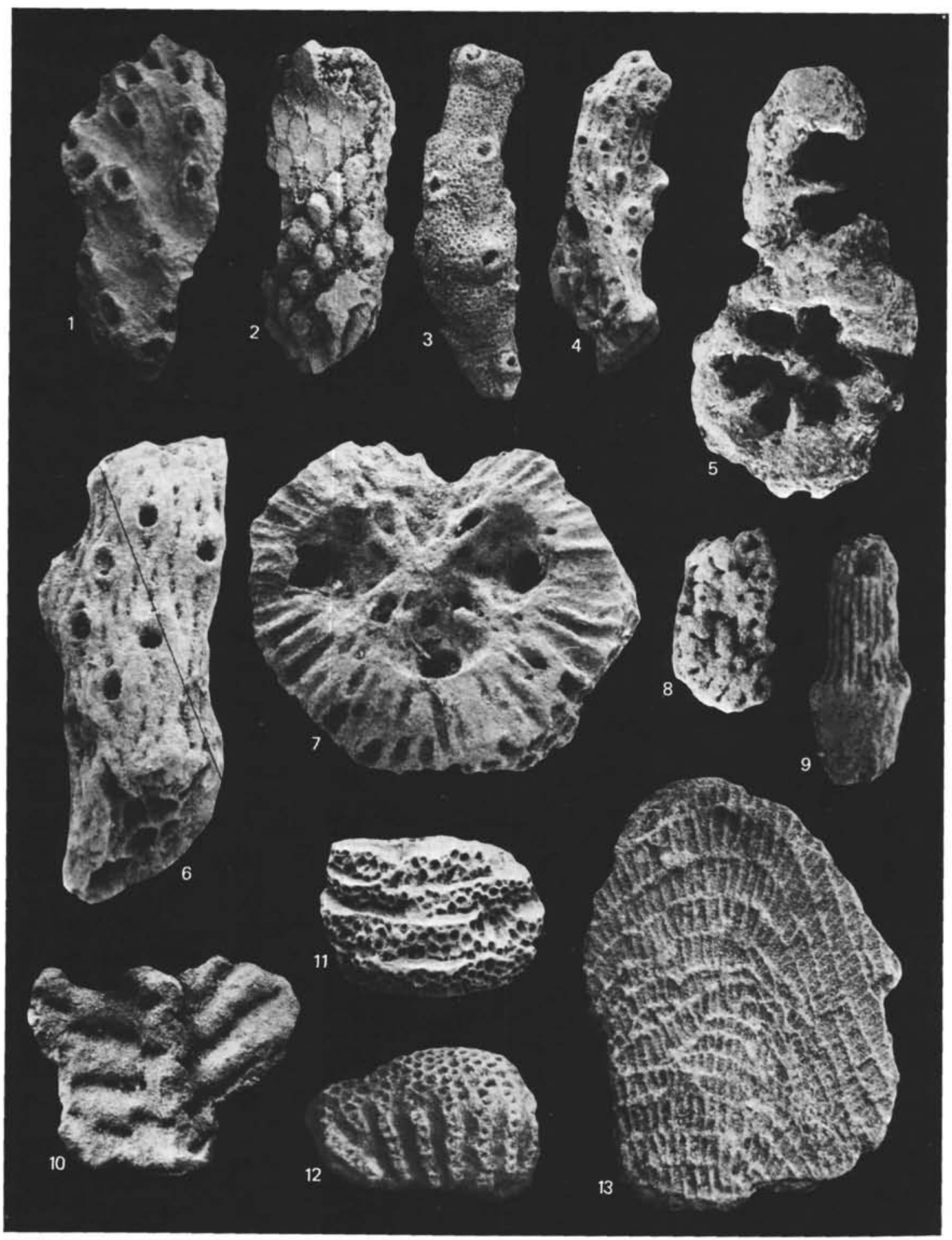

Plate 20. Photomicrographs.

Figures 1, 2. Bryozoan. Leg 61, Site 462 , Core $22-1,69-71 \mathrm{~cm}$, late Oligocene. $\times 18.5$.

Figure 3. Axopora? sp., milleporine hydrozoan. Leg 61 , Site 462 , Core $22-1,69-71 \mathrm{~cm}$, late Oligocene. $\times 18.5$.

Figures 4, 7. Cyclostomate bryozoan. Leg 61, Site 462, Core 22-1, 69$71 \mathrm{~cm}$, late Oligocene. 4. $\times 37.7 . \times 50$.

Figure 5. Stylopora. Leg 61, Site 462, Core $34, \mathrm{CC}$, late Eocene $\times 55$. Figure 6. Seriatopora. Leg 61, Site 462, Core $22-1,69-71 \mathrm{~cm}$, late Oligocene. $\times 53$.
Figure 8. Porites. Leg 61, Site 462, Core 22-1, 69-71 cm, late Oligocene. $\times 18.5$

Figure 9. Echinoid spine. Leg 61, Site 462, Core $51-3,44-47 \mathrm{~cm}$, late Campanian. $\times 45$.

Figure 10. Echinoderm articulate plate. Leg 61, Site 462, Core 22-1, $69-71 \mathrm{~cm}$, late Oligocene. $\times 14$.

Figures 11, 12. Actinastrea? Leg 61, Site 462, Core 22-1, 69-71 cm, late Oligocene. $\times 18.5$.

Figure 13. Alcyonacean, octocorallia. Leg 61 , Site 462 , Core $22-1$, $69-71 \mathrm{~cm}$, late Oligocene. $\times 55$. 